\title{
AN APPLICATION OF FORAMINIFERAL BCOLOGY \\ Vicinity of Horn Island, Mississippi
}

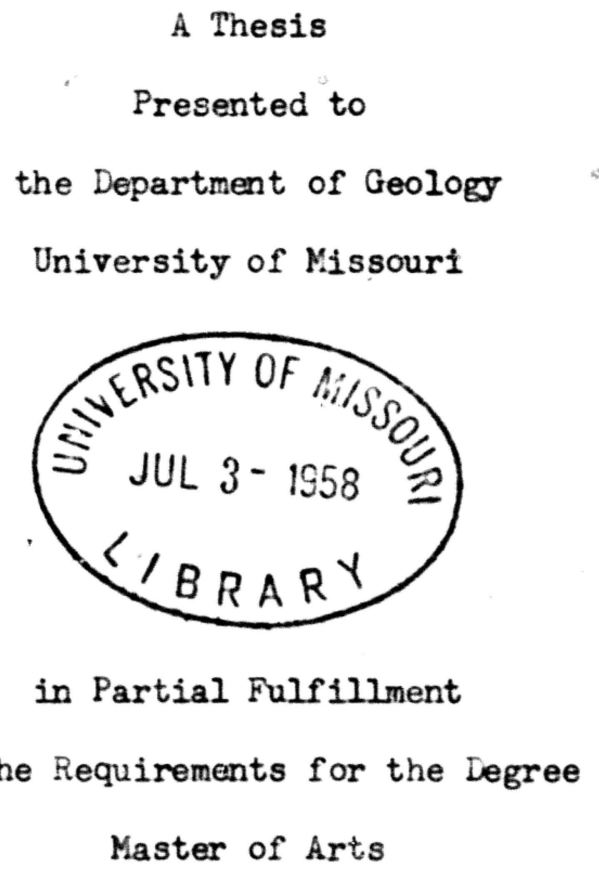

by

William T. Smith

May, 1958 
The undersigned, appointed by the Dean of the Graduate Faculty, have examined a thesis entitled

AN APPIICATION OF FORAMINIFERAL ECOLOGY

Vicinity of Horn IsIand, Mississippi

presented by William T. Smith

a candidate for the degree of Master of Arts and hereby certify that in their opinion it is worthy of acceptance.

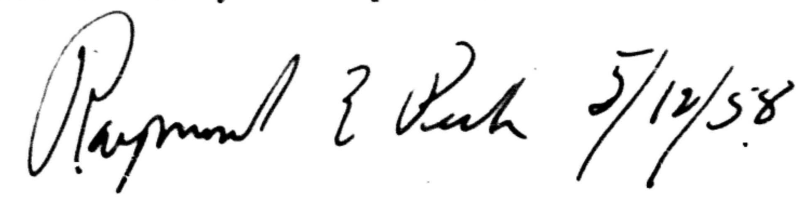
Mauric G. Methls/2, s:o Shluest. A. Ceamplede $5 / 17 / 58$. 
CONTENTS

PAGE

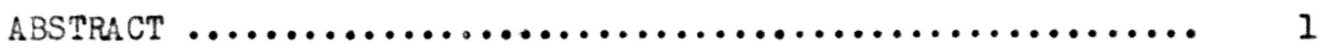

INTRODUCTION $\ldots \ldots \ldots \ldots \ldots \ldots \ldots \ldots \ldots \ldots \ldots \ldots \ldots \ldots \ldots \ldots \ldots \ldots \ldots$

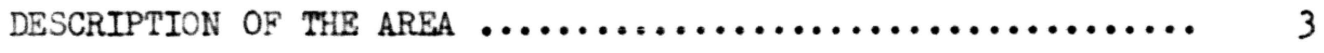

Hydrography $\ldots \ldots \ldots \ldots \ldots \ldots \ldots \ldots \ldots \ldots \ldots \ldots \ldots \ldots \ldots . \ldots \ldots$

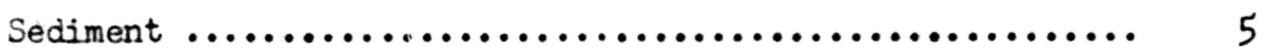

PREVIOUS STUDIES $\ldots \ldots \ldots \ldots \ldots \ldots \ldots \ldots \ldots \ldots \ldots \ldots \ldots \ldots \ldots \ldots \ldots$

METHODS $\ldots \ldots \ldots \ldots \ldots \ldots \ldots \ldots \ldots \ldots \ldots \ldots \ldots \ldots \ldots \ldots \ldots \ldots \ldots \ldots \ldots$

FORAMTNIFERA IN THE SURFACE SEDTMENT $\ldots \ldots \ldots \ldots \ldots \ldots \ldots \ldots \ldots$ I

FORAMINIFERA IN THE CORES $\ldots \ldots \ldots \ldots \ldots \ldots \ldots \ldots \ldots \ldots \ldots \ldots \ldots$

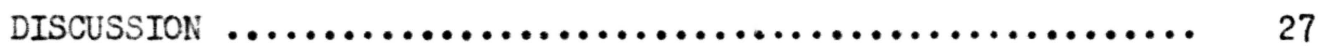

Environmental Interpretation of Core Fauna ............ 29

Points Worthy of Future Examination ............... 34

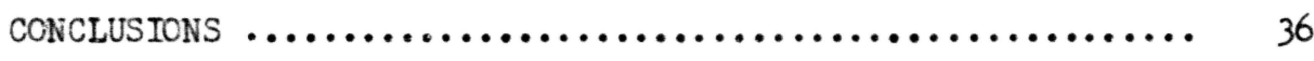

SUGGESTED REFERENCES $\ldots \ldots \ldots \ldots \ldots \ldots \ldots \ldots \ldots \ldots \ldots \ldots \ldots \ldots \ldots \ldots$

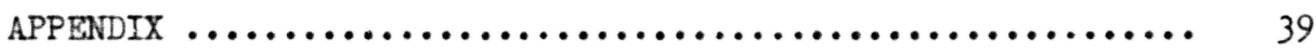

\section{$28659 C$}

$\$$ 


\section{TABIES}

TABLE

PAGE

I PART A BENTHONIC FORAMINIFERAL DISTRIBUTIONS IN MISSISSIPPI SOUND CORES ................ 55

I PART B BENTHONIC FORAM INIFERAL DISTRIBUTIONS IN MISSISSIPPI SOUND CORES $\ldots \ldots \ldots \ldots \ldots \ldots \ldots \ldots \ldots$

II PART A BENTHONIC FORAMINIFERAI DISTRIBUTIONS IN OPEN GULF CORES $\ldots \ldots \ldots \ldots \ldots \ldots \ldots \ldots \ldots \ldots \ldots \ldots$

II PART B BENTHONIC FORAMINIFERAL DISTRIBUTIONS IN OPEN GULF CORES ...................... 58 


\section{FTMURES}

$\begin{array}{ll}\text { FIGURE PAGE } & \text { PUE }\end{array}$

$1 \quad \operatorname{INDEX} \operatorname{MAP} \ldots \ldots \ldots \ldots \ldots \ldots \ldots \ldots \ldots \ldots \ldots \ldots \ldots \ldots \ldots \ldots \ldots \ldots \ldots \ldots$

2 LOCATION OF PISTON CORES $\ldots \ldots \ldots \ldots \ldots \ldots \ldots \ldots \ldots \ldots \ldots . \ldots$

3 GEMERIC DOMINANCE (SURFACE) $\ldots \ldots \ldots \ldots \ldots \ldots \ldots \ldots \ldots \ldots \ldots . \ldots \ldots$

4 DISTRIBUTION OF AMOBACULITES SPP. .............. 12

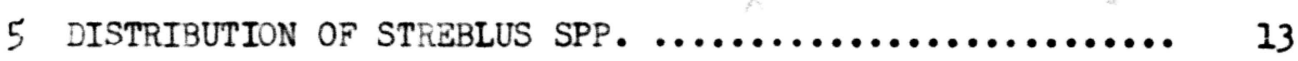

6 DISTPIDITION OF ELPHIDIUM SPP. ..................

7 CORE SURFACE FAUNAL CHARACTERISTICS ............... 17

8 FAUNAL LOG CORB $7419-\mathrm{H} \ldots \ldots \ldots \ldots \ldots \ldots \ldots \ldots \ldots \ldots \ldots \ldots . \ldots \ldots$

9 FAUNAL LOG CORE $7417-\mathrm{H} \ldots \ldots \ldots \ldots \ldots \ldots \ldots \ldots \ldots \ldots \ldots . \ldots \ldots$

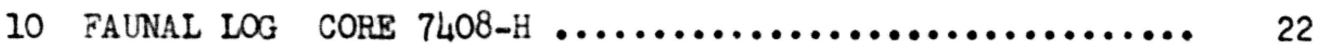

11 FAUNAL IOG CORE $7432-\mathrm{H} \ldots \ldots \ldots \ldots \ldots \ldots \ldots \ldots \ldots \ldots \ldots . \ldots \ldots$

12 INTERPRETED DEPOSITIONAL ENVIPONMENT ............... 30 


\section{ABSTRACT}

Foraminifera were examined in 159 samples cut from 23 piston cores collected in the vicinity of Horn Island, Mississippi. The age of the oldest marine sediment cored is approximately 5000 years. The following data on depositional surface Foraminifera were determined and compared with those data from reports on similar areas: (a) specific composition, (b) percentage of arenaceous Foraminifera, (c) numbers of species, (d) specific dominance, and (e) numbers of specimens. These date show that environments of core samples can be determined by their foraminiferal content and such interpretation utilized to reconstruct the depositional history of an area.

A non-marine clay and sand existed in the area at a time when sea level was lower. As sea level rose, nearshore marine deposition occurred in the present open-gulf area. Alternating brackish and near-marine conditions existed in the present Sound area. A barrier island system, established early in the period of core sediment deposition, offered varying degrees of resistance to the invasion of marine waters. As deposition continued, a "near-delta" influence was impressed upon the area. This influence existed throughout most of the depositional period. At present, a brackich environment exists north of Horn Island and a marine environment occurs south of the island. Mixing of these environments occurs in the passes on each end of Horn Island. The island acts as a barrier to marine water, and brackish water from the Sound now dilutes the open gulf to a greater extent than in the past. The "near-delta" influence is now negligible. 
In recent years, many workers have reported statistical foramii

niferal data and much has been written which correlates Foraminifera with environment. Application of ecologic principles to fossil assemblages is a logical approach to palececology. Foraminifera are increasing in value as additional ecologic data become available. Paleoecology contributes to geology by improving interpretations of paleogeography. Stratigraphic correlation is refined when fossil assemblages can be recognized as specific environmental indicators. A further contribution of paleoecology is that it provides a means of recognizing, in the subsurface, proximity to such features as sand bodies, reefs, and shorelines. This study is an application of criteria obtained from depositional surface foraminiferal. studies to older assemblages. The object of this application is to interpret the depositional environment of each core sample, and to combine these interpretations into a history of the area during core sediment deposition. The older assemblages of this study are geologically recent (approximately 5000 years and less), but environments changed within this period and these changes are indicated by the Foraminifera.

Dr. William R. Walton guided the initial efforts of this study. The samples, laboratory, and library facilities were furnished by Gulf Research and Development Company. The writer gratefully acknowledges the help of Mrs. Helen Hensenne who typed the thesis, and Mr. Paul Fiehler and liss Theresa Provenzo who drafted the figures and tables. The suggestions of Dr. Raymond E. Peck, Dr. M. G. Mehl and Mr. John Wall, who read the manuscript, are also appreciated. 


\section{: \\ DESCRIPTION OF THE AREA}

The area extending from $30^{\circ} 09^{\prime}$ to $30^{\circ} 20^{\prime} \mathrm{N}$. latitude and $88^{\circ} 28^{\prime}$ to $88^{\circ} 48^{\prime}$ ' W. longitude includes the eastern one-third of Iog Keys Pass, Horn Island, Horn Island Pass, the western end of Petit Bois Island, and the interval from one-half mile off the Mississippi coast to approximately 5 miles south of Horn Island, Mississippi (Figure 1). The area is approximately 220 square miles.

Hydrography

Horn Island, one of a series of sand islands extending from Kobile Point to the St. Bernard subdelta, is an effective barrier to the invasion of marine water into Misisissippi Sound. The Pascagoula River drains into the northern part of the area. The prircipal enviranments in the area are Mississippi Sound, Horn Island, the two passes, and the open gulf. The maximum water depth sampled is 44 feet. Comparison of modern charts with those of 1860 indicates very little change in water depths. A few current measurements in the Sound have been recorded (John C. Ludwick, personal comnunication) and these currents were negligible. This suggests very little transportation of sediment in the Sound. Current's are considerably stronger in the passes and sediment is transported in this area. Air temperatures, measured in September (John C. Ludwick, personal communication), are approximately $28^{\circ}$ C. The Mississippi Sound and opengulf waters are isothermal, and the temperature is approximately $28^{\circ} \mathrm{C}$. Salinity, measured in April and May (John C. Ludwick, Personal cmunication), varies from 24 to 30 parts per thousand in Mississippi Sound. Measurements in September average 26 parts per thousand for bottom waters 


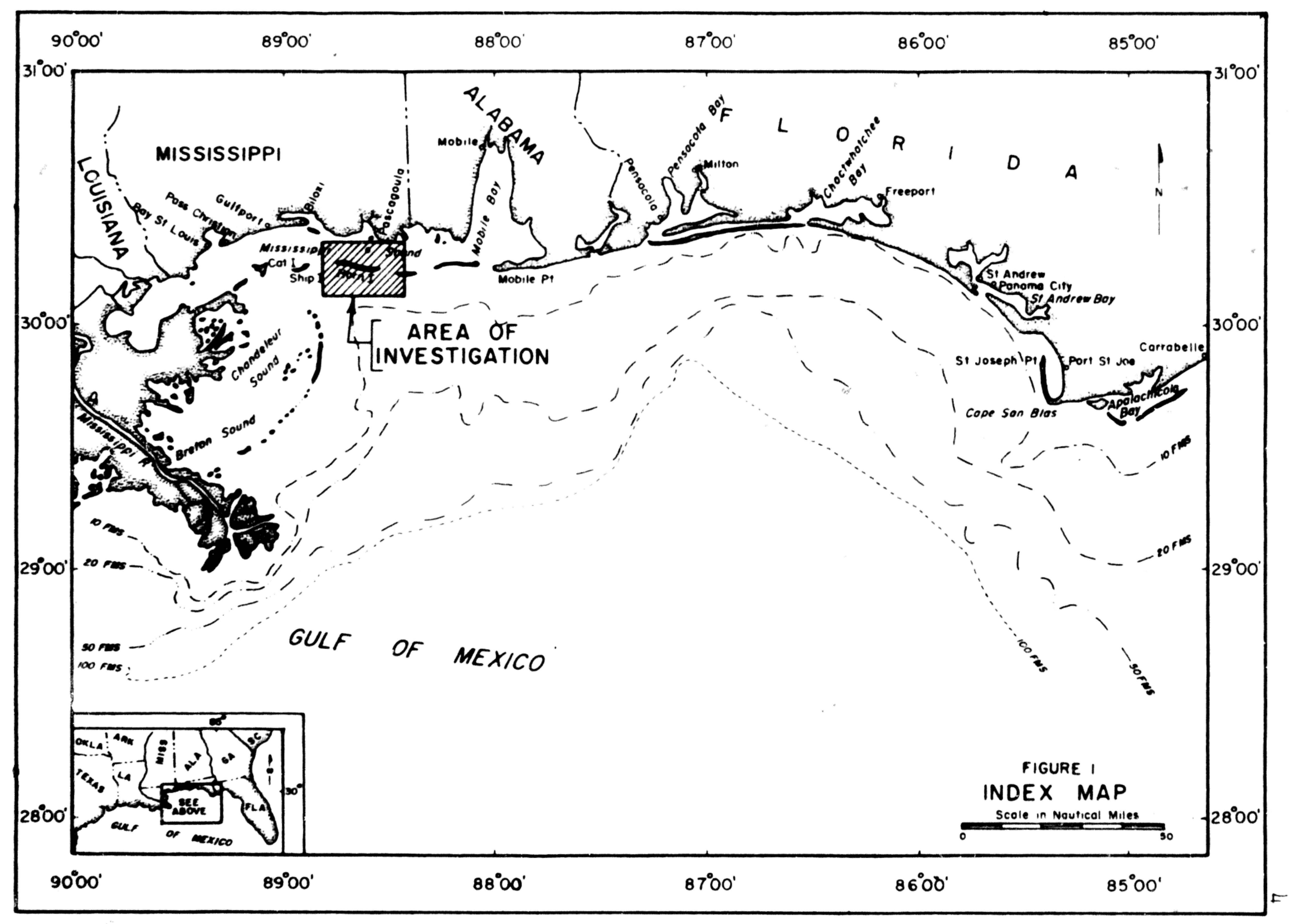


in Mississippi Sound and 30 parts per thousand for bottom waters in the open sulf.

Sediment

The dominant sediment in Mississippi Sound is black, fetid nud (C. S. Wimberley, personal communication). Sand is common as discontinuous units but silt is lacking in the Sound. Horn Island is composed of well-sorted, fine to medium-grained quartz sand. A long narrow troughs parallel to Horn Island and immediately north, contains fine-grained mud. Sediment in the open gulf consists of both sand and mad but the amount of mad decreases rapidly of fshore. 
PREVIOUS STUDIES

Forzminiferal data from this area have been published by Phleger (1954). Additional data from related areas are reported by Parker et al. (1953), Walton (1954), and Phleger (1955) The environmental significance of the comnon Foraminifera can be determined from these data. Specific distributions ere well defined in the above reports. Phleger (1954, p. 603) recognizes a distinct calcareous-arenaceous foraminiferal boundary. In the same report (p. 591), Phleger establishes that numbers of species are larger in the open gulf than in Mississippi Sound. Walton (1956, unpublished data) characterizes the Foraminifera near Horn Island in terms of numbers of species, percentage occurrence of the dominant species, percentage of arenaceous Foraminifera, numbers of specimens, and sharpness of faunal bcundaries.

Data from the above reports indicate that, for this area: (a) generic distributions are environmentally controlled; (b) numbers of species and numbers of specimens increase with distance from shore; (c) percentage of arenaceous Foraminifera and specific dominance decreases with distance from shore; and, (d) foraminiferal boundaries become sharper with proximity to shore.

The quantity of data available and the number of environments included in the previous studies, combined with data herein presented, permit rather accurate interpretation of the environments indicated by the core Foraminifera. 


\section{METHODS}

Twenty-three cores were collectea in the vicinity of Horn Island, Mississippi (Figure 2). They were collected in 1955 aboard the GRADCO Pioneer with a piston-type coring device. This device obtains a maximum core of 26 feet. It operates with a system of gears that permits a 4 to 1 recovery of sediment with drop of the weight pan. Aluminum tubes, lining the core barrel, were removed aboard ship and cut into sections approximately 4 feet long.

Sediment in the core sections was extruded in the laboratory by means of $a$ winch and a wooden plunger equipped with a rubber stopper. Some sections had to be milled open when the winch and plunger were unsuccessiul. Foraminiferal samples were cut at intervals of approximately 20 inches and each conspicucus lithologic unit was sampled. The samples are uniform in volume, one inch in length and one-half the core diameter in width. Sediment from the exterior of each sample was removed to avoid contamination. The resulting volume of each sample is approximately 23 ç. A total of 159 samples were washed over a 230 mesh screen, examined wet for fecal, vegetative and chitinous matter, and allowed to dry. The Foraminifera in the dried samples were concentrated by floating in carbon tetrachloride, and the residue of sample was examinged for non-floating organisms. Samples containing large numbers of specimens were split, prior to concentrating the Foraminifera, with an Otto microsplitter (Otto, 1933) and a minimum of 300 specimens per sample was counted (Dryden, 1931 ). Species populations were counted in 95 samples (Tables IA,B; IIA,B; III) and Foraminifera in the remainder of the samples were visually estimated. s. 


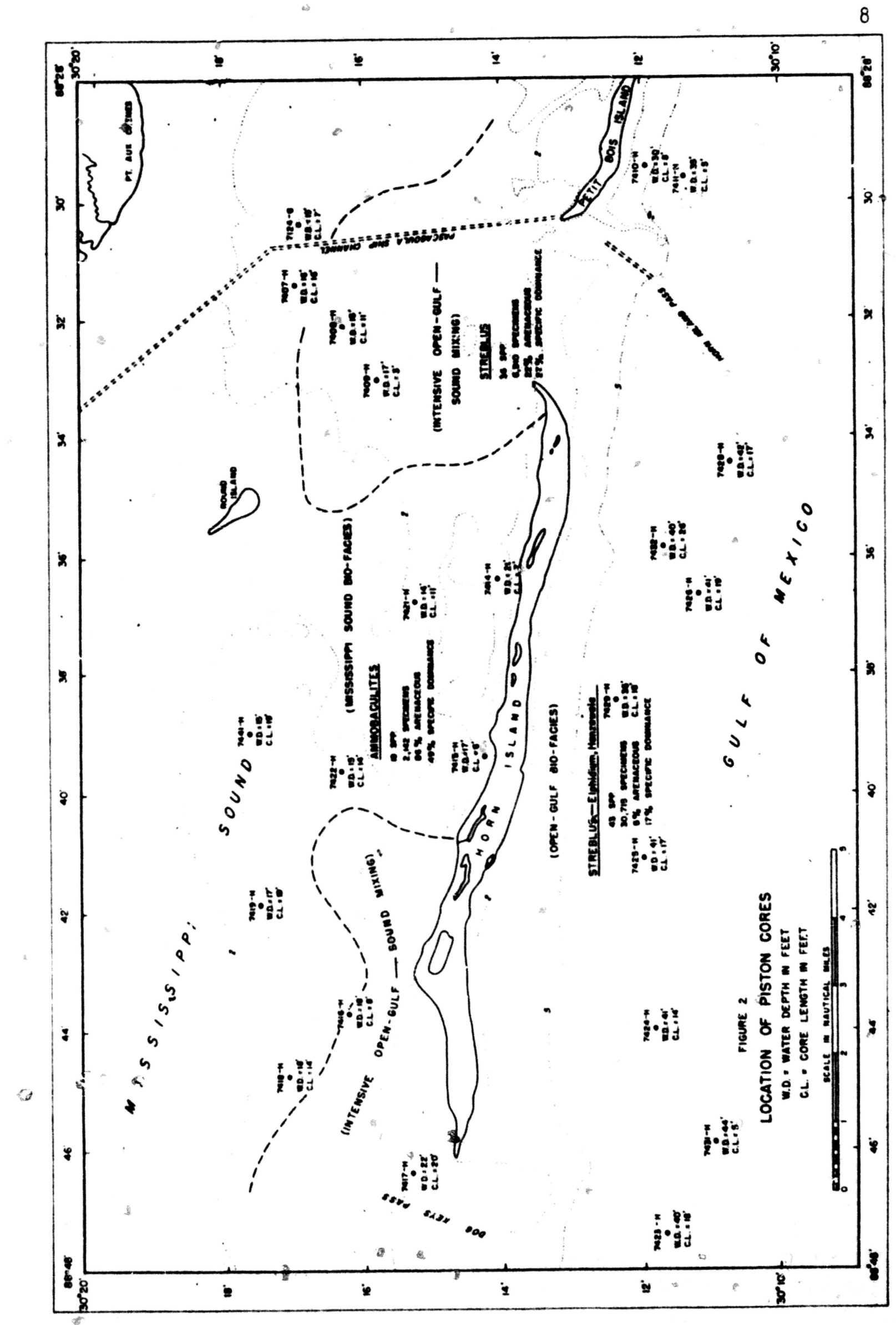


The estimates consist of counts of numbers of species, estimates of percentage ocqurrence of each species, and estimates of total mumbers of specimens.

Portions of the Mississippi Sound, open gulf, and mixed environments are included in this study. The dominant genus and average value. per sample of numbers of species, numbers of specimens, percentages of arenaceous Foraminifera, and percentage occurrence of the dominant species can be determined for each environment (Figure 2). These averages, obtained from core-surface data, are in agreement with data of Phleger (1954) and Walton (1956, unpublished data). Generic dominance can be determined. by combining these data (Figutre 3).

둔 


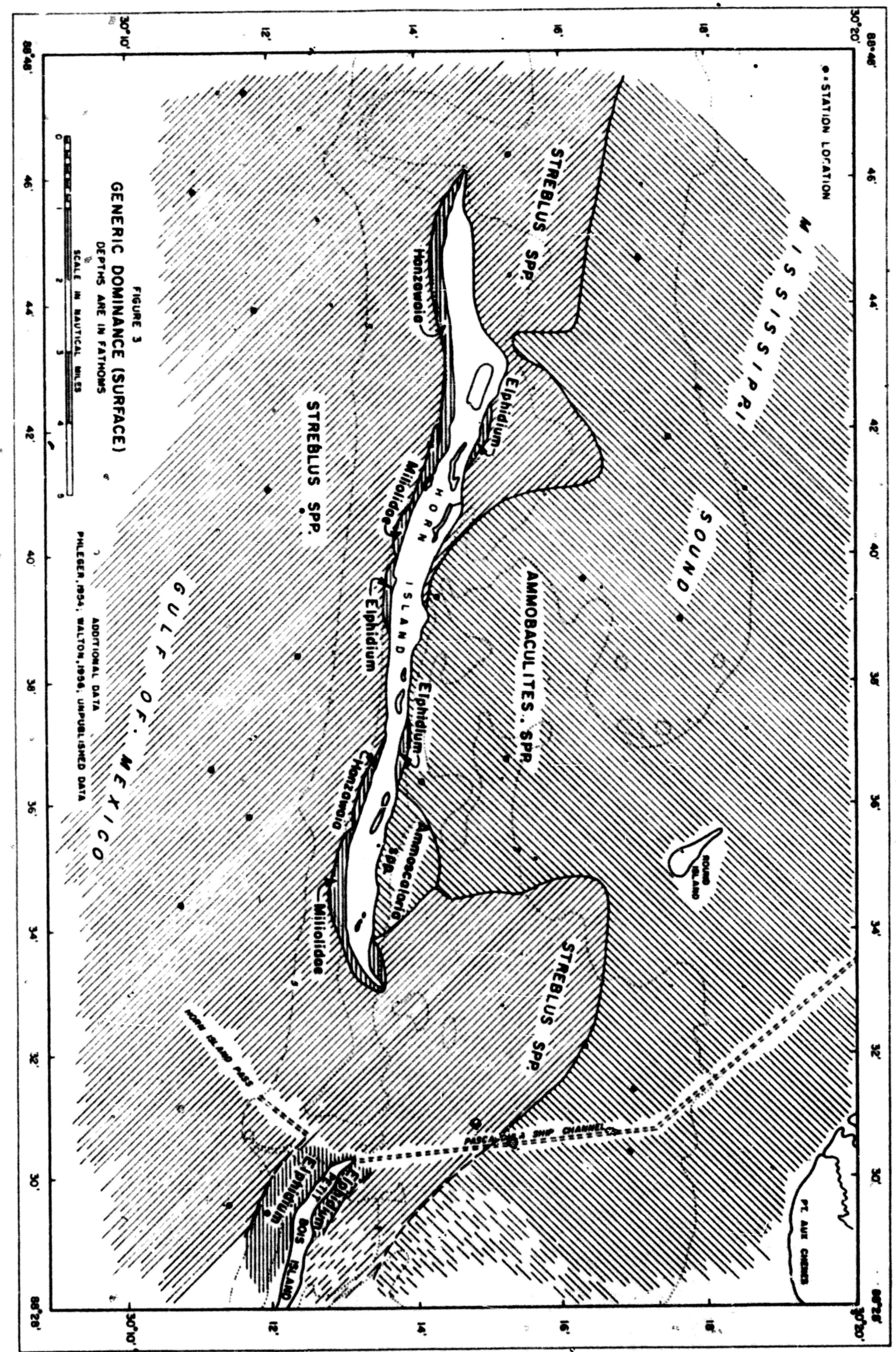


FORAMINIFERA IN THE SURFACE SELIMIENT

Ammobaculites spp. (chiefly A. salsus Cushman and Bronnimann) and Streblus beccarif (Iinne) are, by far, the most common species in the surface sediment of this area. Ammobaculites, essentially restricted to Mississippi Sound, constitutes more than one-half the fauna in the majority of Sound samples. The rapid decrease in percentage occurrence of this genus near areas of open-gulf influence is striking (Figure 4). Streblus beccarif dominates the fauna of the majority of open-gulf and mixed environment samples (Figure 5). Elphidium (Figure 6) commonly is associated with Streblus and occasionally dominates the fauna of samples within the Streblus "zone". Hanzawaia strattoni (Applin) and the Miliolidae are essentially restricted to the open gulf. These forms occasionally dominate the fauna of a few, sparsely populated, beach or nearshore samples (Figure 3). Bulliminella spp. (chiefly B. elegantissima (d'Orbigny)) and Nonionella spp. (chiefly N. atlantica Cushman and N. opima Cushman) are not abundant in the surface sediment of this area. These species are abundant within the cores, however, and their surface distribution deserves mention. Buliminella seldom constitutes greater than 5 percent of the fauna landward from a distance of 2 miles south of Horn Island. Nonionella usually comprises less than 15 percent of the fauna in the open gulf and generally less than 2 percent in the Sound and mixed environments.

A distinct arenaceous-calcareous foraminiferal boundary occurs in the area (Figure 4). Ammobaculites constitutes the major element of the Sound ardaceous Foraminifera; therefore, the distribution of this genus सत? 


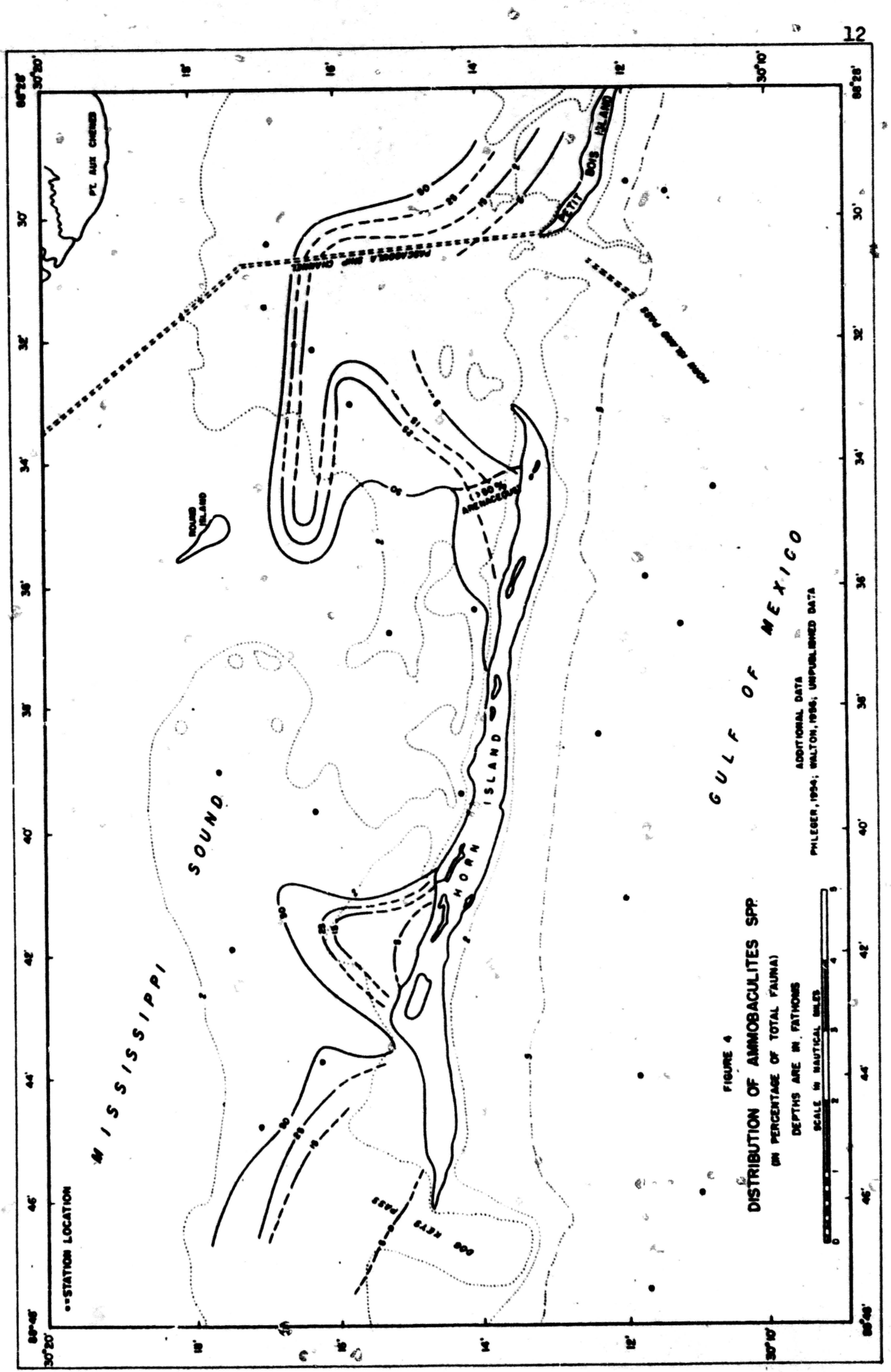




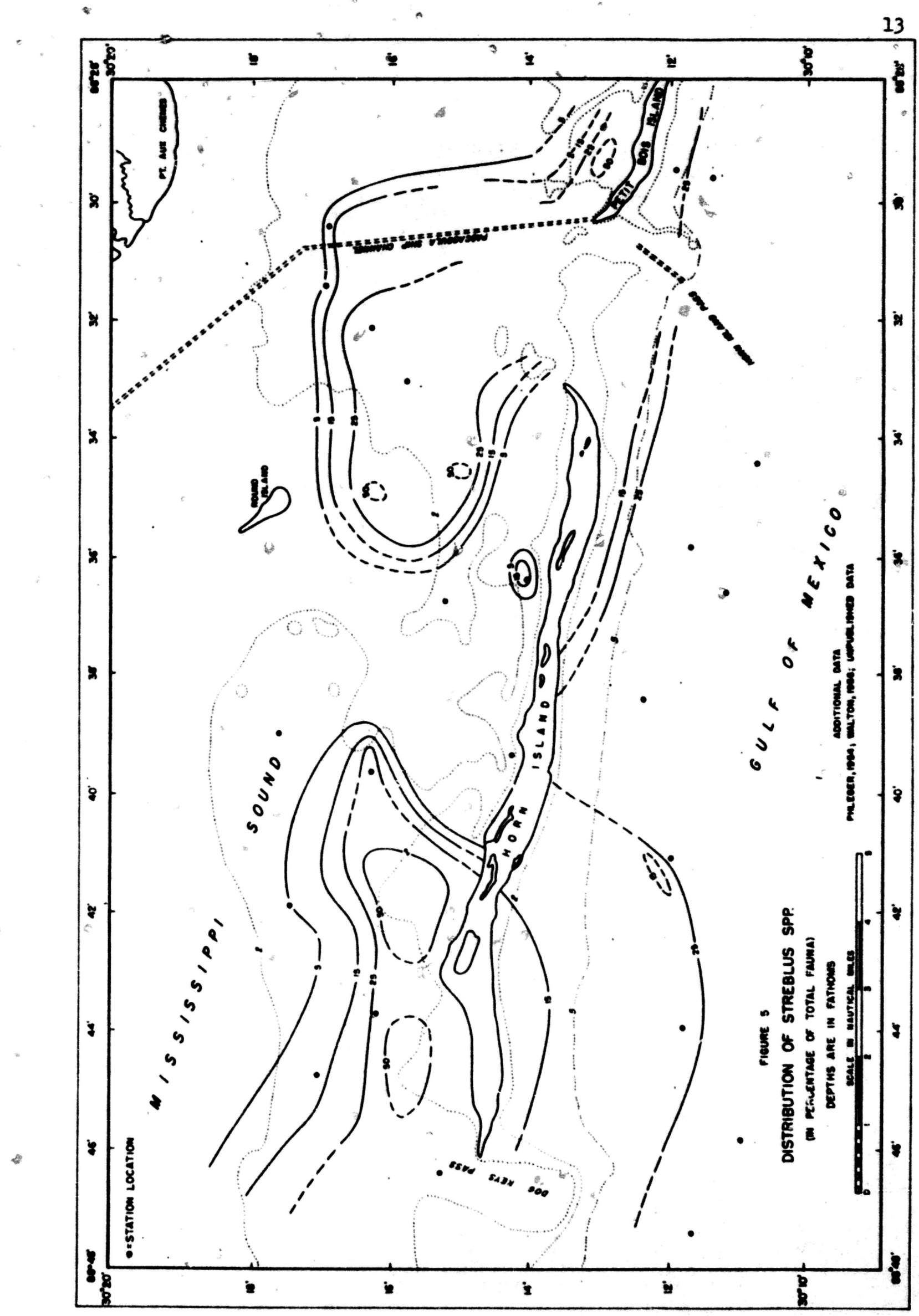


14

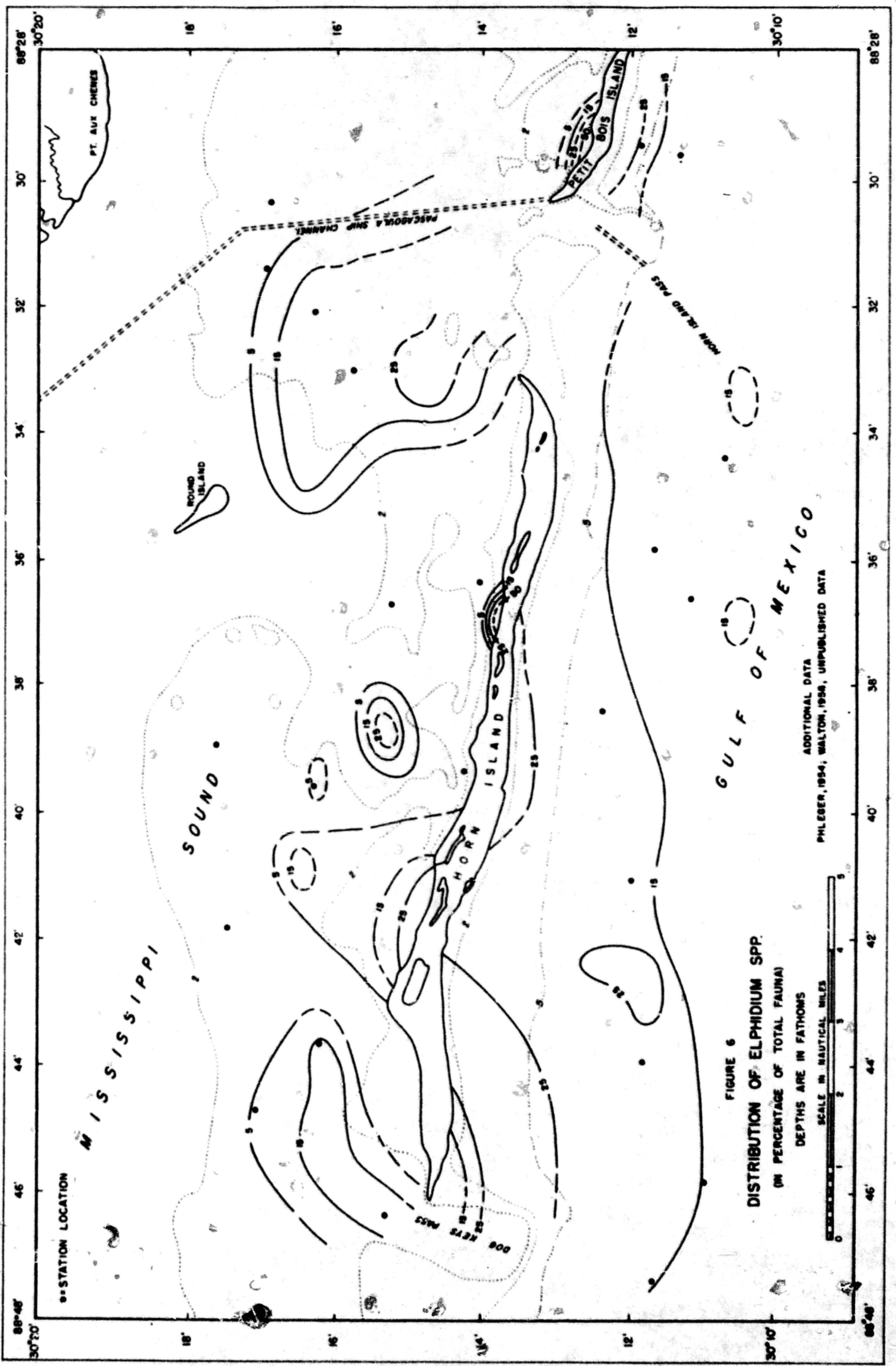


defines the arenaceous-calcareous boundsry. The 50 percent contour is indented shoreward in areas of marine influence but extends, to the barrier island in the central part of the area. The percentage of arenaceous Foraminifera is markedly decreased in areas of intensive marine influence. In the open gulf, arenaceous Foraminifera usually constitute less than 10 percent of the faura.

Numbers of species per sample and specific dominance (expressed as the percentage occurrence of the dominant species) are, in general, inversely proportional. In the Sound, samples contain an average of 18 species and the dominant species constitutes an average per sample of 49 percent of the Fauna. The mixed environment surface samples contais Intermediate values for these two faunal characters. The average number of species per sample is 36 and the average specific dominance value is 27 percent. In contrast to the Sound, the open-gulf samples contain an average of 43 species and a specific dominance value of 17 percent. The density of the foraminiferal population can be determined by combining and adjusting data to represent a uniform volume of approxdmately $23 \mathrm{cc}$. Data from core surface samples, grab samples, and PBS samples were usod. Two areas of large populations occur in the Horn Island vicinity. The area of largest population, greater than 25,000 specimens per sample, occurs at a distance of approxinately $1 \frac{1}{2}$ miles south of Horn Island. Numbers of specimens decrease rapidly in the direction of the ieland where, on the beaches or very near shore, there are less than 1000 specimens per sample. The area of large numbers of specimens in the Sound, approximately 5000 specimens per sample, occurs 
at a distance of about one mile north of Horn Island. Numbers of spec1mens per sample decrease stroreward toward Horn Island and the Mississipp1 coast.

Core surface foraminiferal characters, excluding generic and specific composition, can be plotted as in Figure 7. Bach point, representing a core surfase sample, is plotted on a number of species - specific dominance scale. The broken lines group the samples. The brackets within each group contain the average values per sample of percentage of arenaceous Foraminifera and number of specimens. The crossmark represents the "average" sample on the number of species - spec1f1c dominance scale. Numbers of species and numbers of specimens decrease as Sound conditions are obtained. The percentage of arenaceous Poraminifera and the specific dominance increase as Sound conditions are obtained.

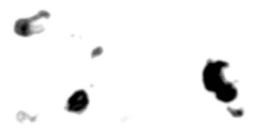




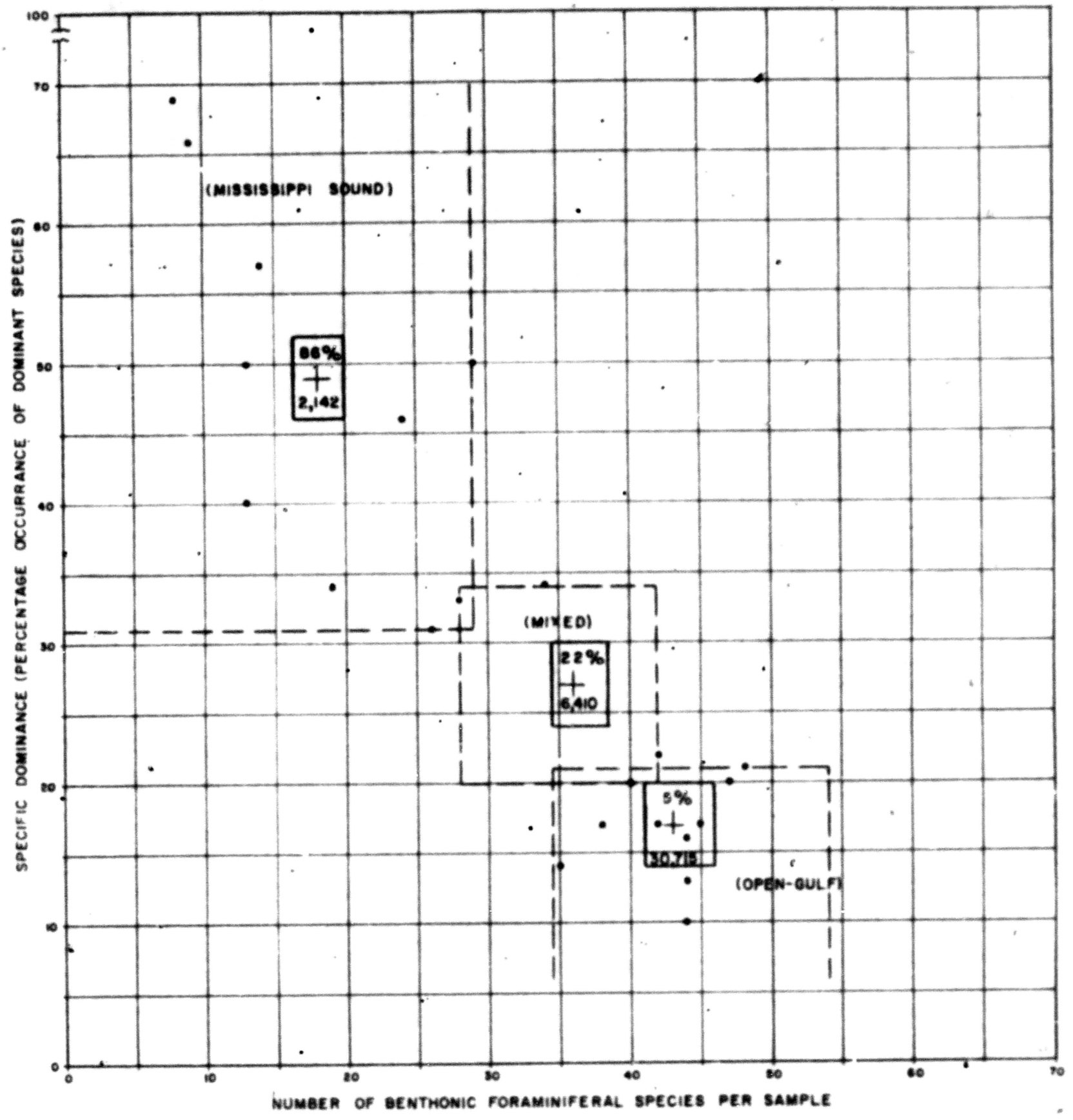

FIGURE 7

CORE SURFACE FAUNAL CHARACTERISTICS

Averoges for orea

c.

\%ertenecenus

+ Spp. ve. Geminence

Eenthenic populetion

os sunface sample 
FORAMINIFERA IN THE CORES

The twenty-three core locations are distributed so that nine occur in the Sound environment, four occur in the mixed environment, and ten occur in the open gulf. Seventy-six samples were cut from the Sound cores and sixty-six of these samples contained Foraminifera. Of the twentyeight samples cut from the mixed environment cores, twenty-five contain Foraminifera. Fifty-five open-gulf core samples were examined and fifty were found to contain Foraminifera.

Ammobeculites, Blphidium, Streblus, and Buliminelin dominate the Sound cores fauna. Amobaculikes is dominant in more than half the samples. Blphidium is commonly dominant and, in some samples, it co-dominates with Streblus. Buliminella, rare or absent at the surface, dominates the fauna of about 10 percent of the Sound core samples. In the mixed environment cores, Blphidium and Streblus are, by far, the most common genera. Ammobaculites and Trochammina dominate the fauna of a few mixed environment core samples. In the open-gulf cores, in contrast to the Streblusdominant surface fauna, Buliminella and Elphidium dominate the fauna of more than three-fourths of the samples. Nonionella is dominant in about 10 percent of these samples, and Streblus, Hanzawaia, or Rosalina dominate the fauna of the remaining samples.

In practically all of the Sound core samples, Amobaculites, Blphidium and Streblus are abundant or very common. Buliminella, Bolivina and Miliolidae are less commor, but they are significant at the 20-60 inch level and restricted to it in most samples. In the majority of the mixed environment core samples, Streblus and Blphiddum are abundant se very common. Ammobaculizes and Trochamina are rather common in the low parts 
of these cores. In the open-gulf cores, Blphidium is abundant. Buliminella is consistently abundant within the cores but only in core $7425-\mathrm{H}$ is it abundant at the surface. Streblus is rather common in most of the samples but it is abundant only in the surface and near-surface samples. Rosalina, Nonionella, Hanzavaia, Bolivina, and the Miliolidae are often more common than Streblus.

The surface relationship of arenaceous and calcareous Foraminifera is maintained within the cores. The average percent per sample of arenaceous Foraminifera is largest in the Sound cores, intermediate in the mixed environment cores, and smallest in the open-gulf cores. The percentage of arenaceous Foramintfera in Sound cores is highly variable (Figure 8) and is cyclic in occurrence. Fauna of the Sound core samples contains an average of about 50 percent arenaceous Foraminifera. In the mixed environment cores, the percentage of arenaceous Foraminifera does not vary so consistently (Figures 9, 10). Fauna of the mixed environment core samples contains an average of 16 percent arenactous Foraminifera. The open-gulf core samples contain an average of 2 percent arenaceous Foraminifera. This sparse, arenaceous fauna is dominated by Bigenerina Irreqularis Phleger and Parker, typically an open-gulf species. The surface ralationships of numbers of species between Sound, mixed, and open-gulf environments is maintained within the cores. The average value of numbers of species per sample is smallest in the Sound cores, internediate in the mixed environment cores, and largest in the open-gulf cor $\epsilon s$. The Sound core samples contain an average of 10 species. Indicative of the rapid rate of change in the nearshore brackish environment, some of the longer Sound cores contain evidence of two complete 


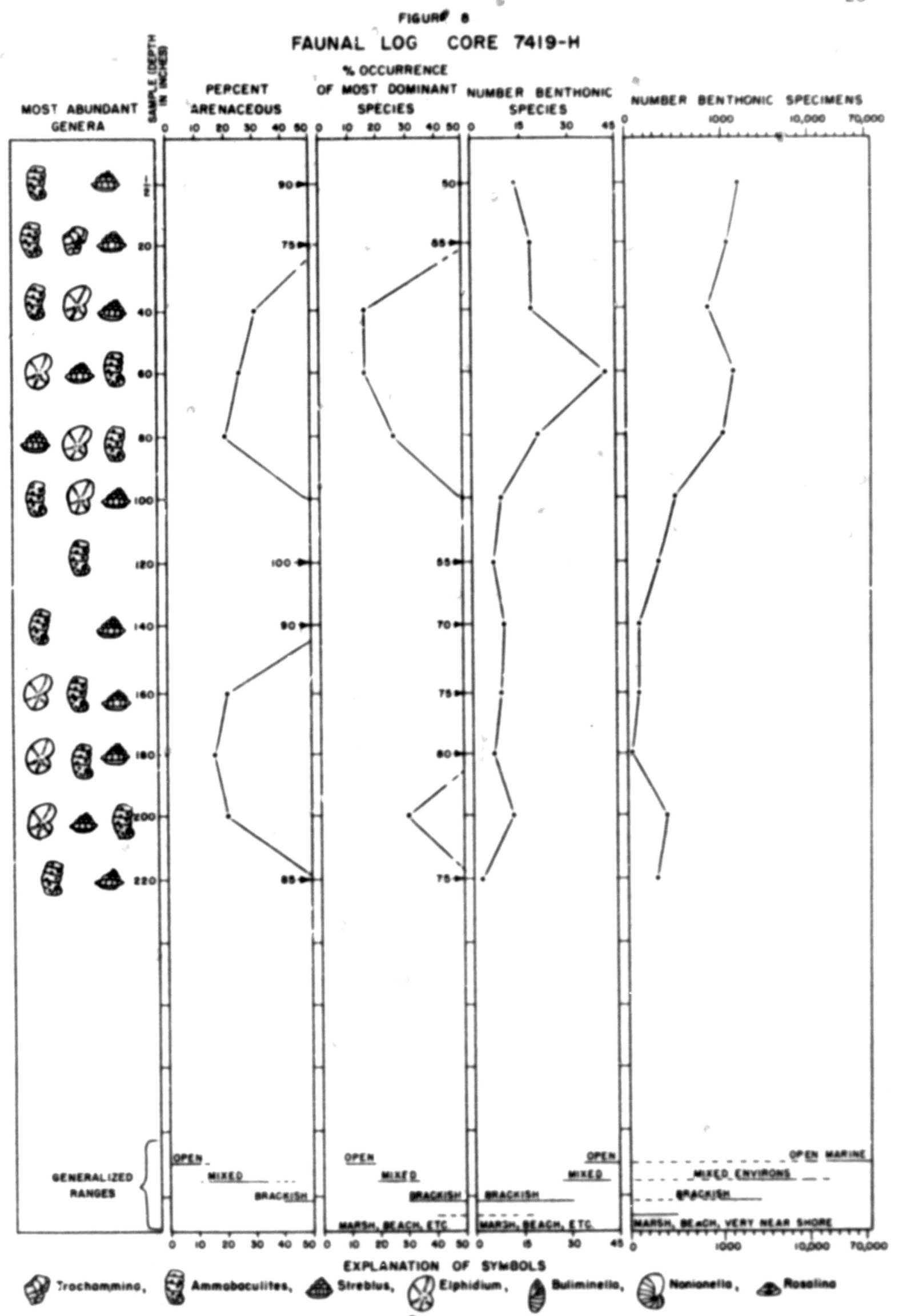


FIGURE 9
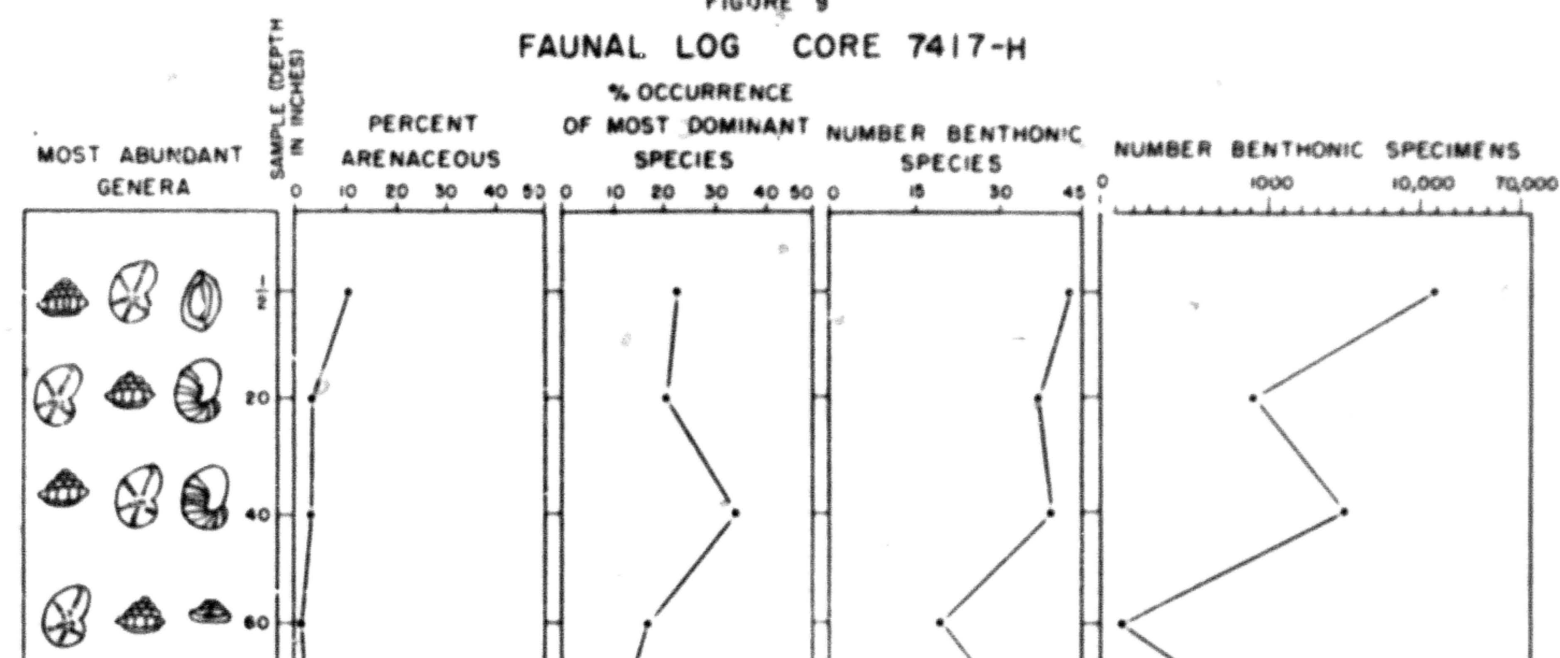

$8 \rightarrow$

$B \rightarrow$ B.

(2) $\rightarrow$

(3)

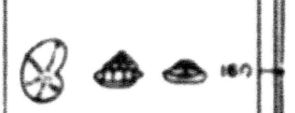

200

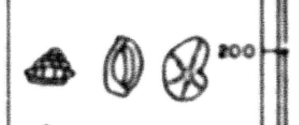

(1) $\rightarrow$

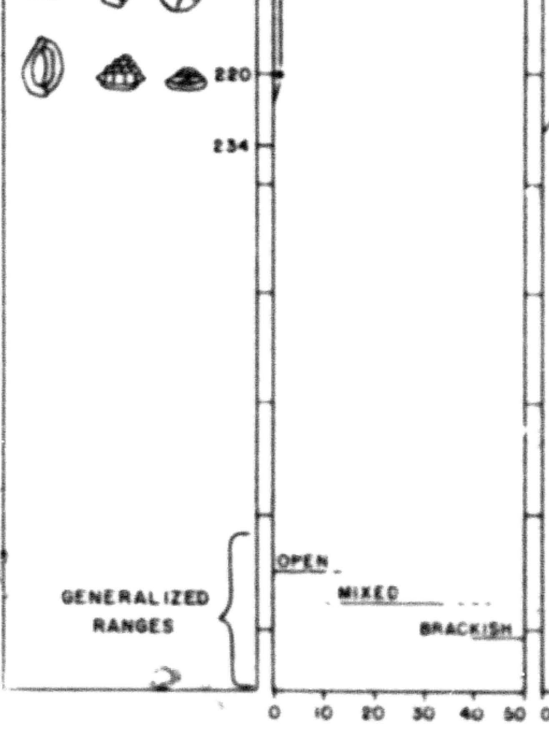

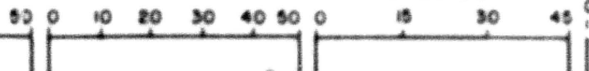

Trochemmino, 10 Ammobacuites,

\section{EXPLANATION of srmeols}

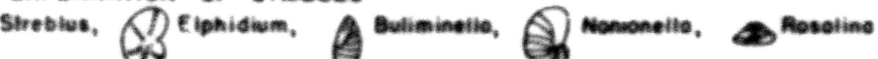


FIGURE 10
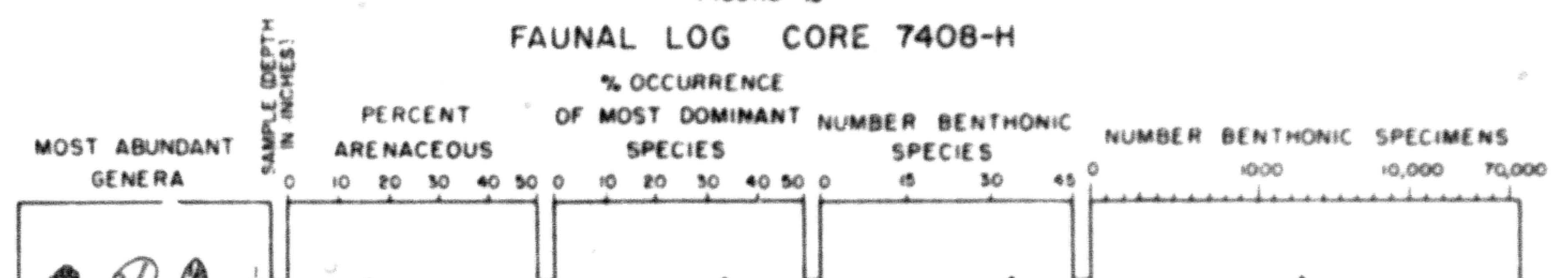

- 8 果

6

Q 8.0 .

里。 年

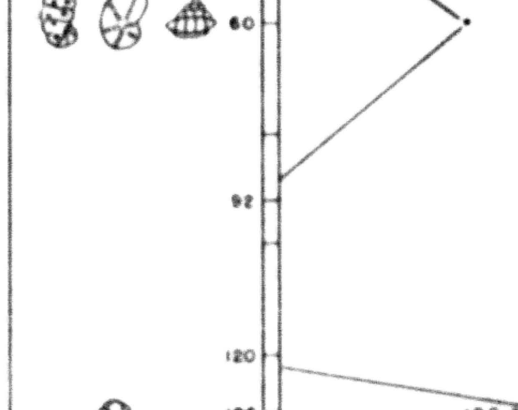

2

色

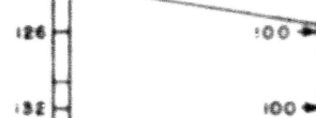

$100+1$
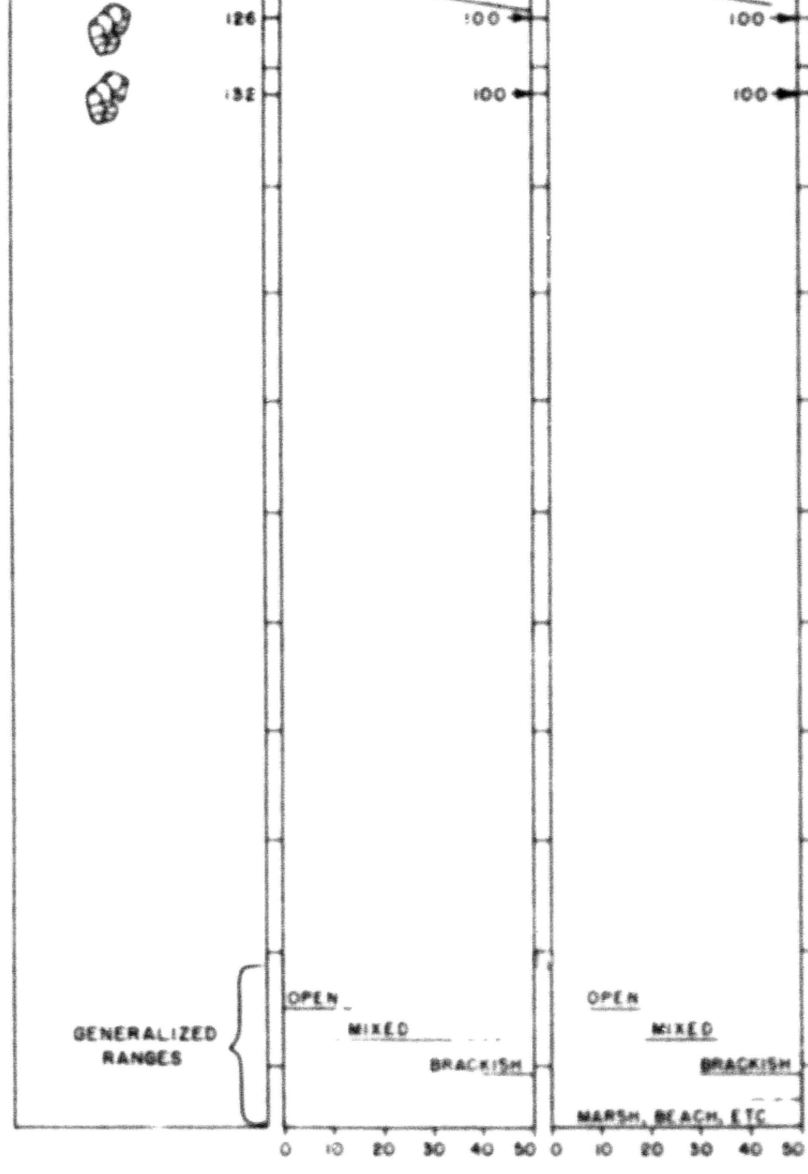

83

Trochemmine, 80 Ammoboculites,

EXPLANATION OF srMBols

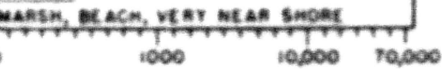

opts $\$$ *ixe

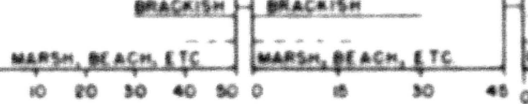

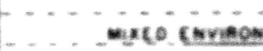

ocs wast 
cycles in the number of species character (not well-developed in Figure 8). The mixed environment core samples contain an average of 27 species. Numbers of species generally decrease with depth in these cores. The opengulf core samples contain an average of 36 species. Numbers of species . in these samples are relatively uniform and decrease only in the lower parts of the longer cores (Figure 11).

The surface relationship of specific dominance is maintained within. the cores. The Sound cors samples contain dominant species which const1tute about 34 percent of the fauna. Cyelic occurrences of specific dominance are conspicuous in some of the longer Sound corec (Figure 8). The mixed environment core samples contain average specific dominance values of 28 percent. The open-gulf core samples contain average specific dominance values of 20 percent. A slight increase in this character can be noted at depth within the open-gulf cores.

Values for number of specimens per sample maintain the same relationship within the cores as at the surface. Average vaiues of numbers of specimens per sample are smallest in the Sound cores, intermediate in the mixed environment cores, and largest in the open-gulf cores. Nost core samples contain fewer specimens than those samples taken at the depositional interface. Numbers of specimens are cyclic in some of the Sound cores.

In comparing the various faunal characteristics of all the cores, seversl significant features become apparent. The average values for the faunal characteristics of each group of cores are smaller in most sanples, but remain within the ranges established' from the surface faunal data. The relationships of faunal characteristics from core group to core group 
FIGURE II

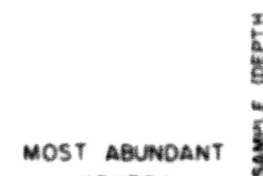

FAUNAL LOG

CORE 7432-H

\% occuarence

GENE RA

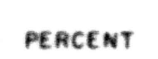
ARE NACEOUS

OF MOST DOMINANT NUMEE R EENTHONIC

SPECIES SPECIES

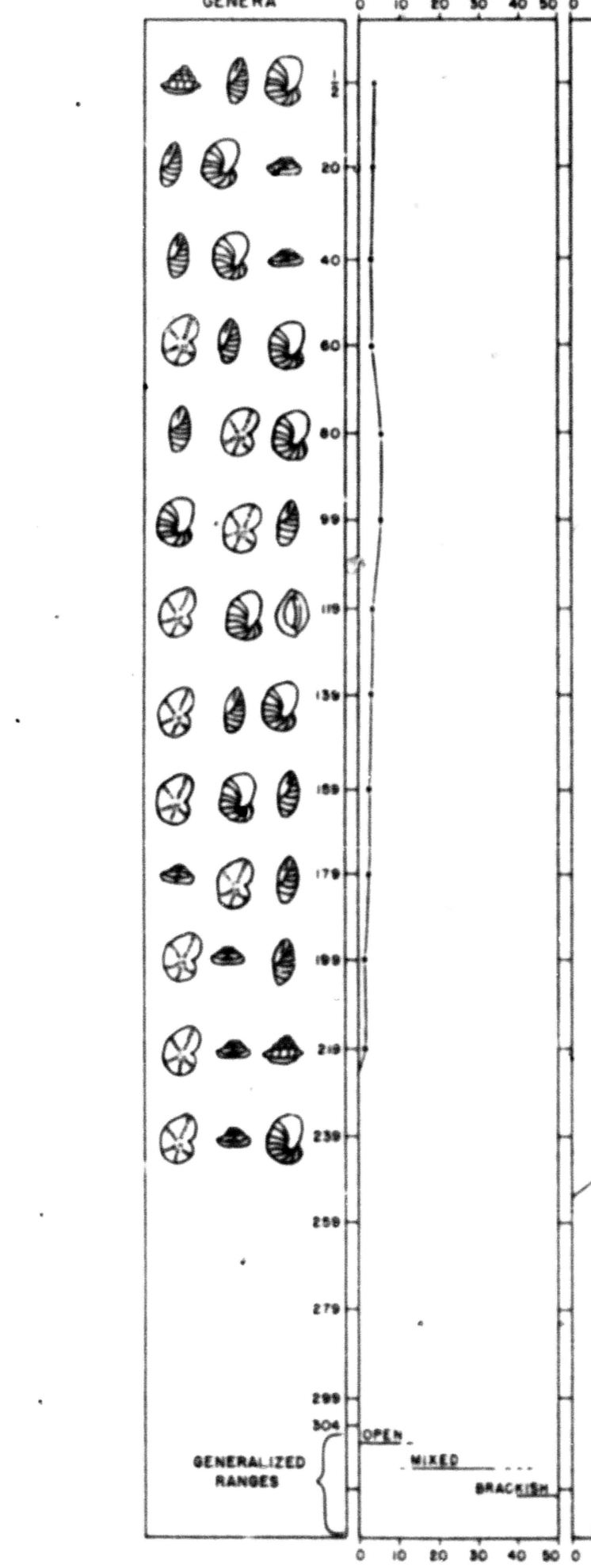

$10.00-30=0$

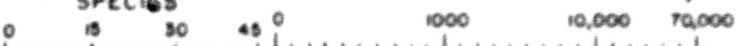

.

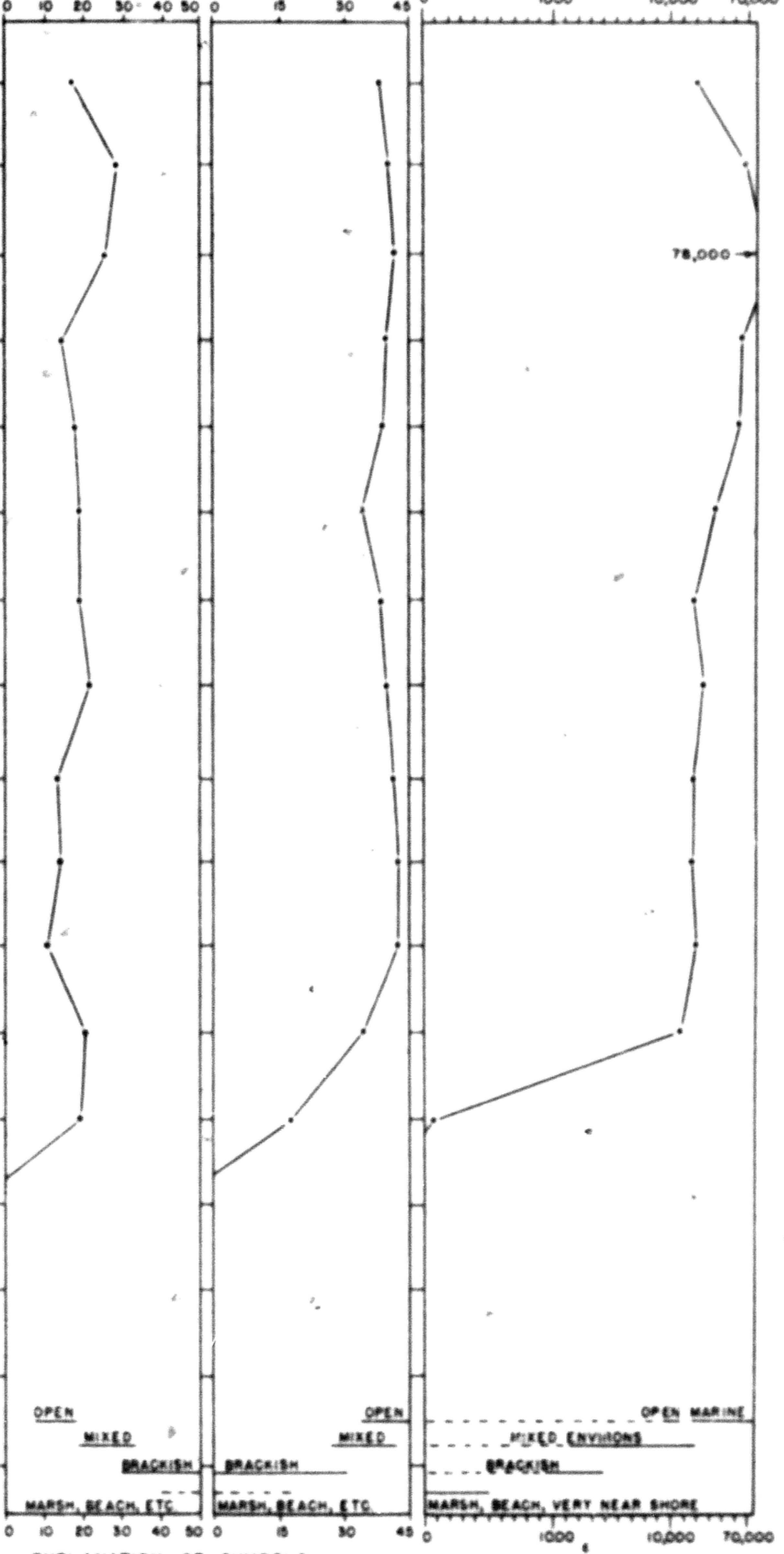

C) Trochommino, Ammoboculites.

EXPLANATION OF STMBOLS

sistolus, 7 Eiphidium,

(Q) Mitiotldee

Buliminetia,

A Nonionetie.

2) Rovesino 
are the same as at the surface; for example, numbers of species per sample are smaller in the Sound cores than in the open-gulf coree and values of dointuance in the Sound cores are larger than in the open-gulf cores. In addition to relationships of faunal characteristics, another feature is emphasized by the core faunal data. The abrupt changes present in the Sound surface characteristics are reflected in the Sound cores. This rapid rate of change emphasizes the relative instability of environants in the Sound. The cyclic occurrences in numbers of species, percentage arenaceous Foraminifera, speciflc dominance, and numbers of specimens are characteristic of the Sound cores.

The changes in faunal characteristics with depth in the cores can be illustrated with faunal logs (Figures $8-11$ ). The ranges are based on data obtained from surface samples. Four of the five faunal characteristics are applicable to older sediment where recent genera may not exist. The rapid faunal changes ciaracteristic of nearshore, brackish environments can be illustrated with the Sound core faunal log (Figure 8 ). Large values of dominance and percentage arenaceous Foraminifera, and small values of numbers of species and numbers of specimens are illustrated with this $\mathrm{log}$. In contrast, the relatively uniform environment persisting throughout most of the open-gulf section is 1liustrated with Figure 11. The dissimilarity in faunal characteristics of Figures 8 and 11 is striking. In Figure 11, numbers of species and numbers of specimens are large while percentage arenaceous Foraminifera and specific dominance are small. Figures 9 and 10 are logs of two mixed environment cores. Intermediate values for most of the faunal characterist $k$ s are 
illustrated with these logs. In adilion the rate of change in faunal characteristics of these logs is intermediate between that of Figures 8 and 11 .

Bighteen of the samples contain few or no Foraminifera. The faunas in these samples are so inconsistent in number of specinens, specific composition, or environmental sigrificance that contamination undoubtedly is responsible. The sediment in most of these barren samples is a stiff, gray, or mottled dark green and reddish-yellow clay. A gray wood-imbedded clay directly overlies this varicolored clay in some cores. Carbon 14 dating of wood from the same horizon near Point Aux Chenes, Mississioni, Indicates an age of approximately 5000 years (John C. Ludwick, personal cormunication). 
DISCUSSION

Values for most faunal characters, when averaged for the various cores, are uithin the ranges of those existing at the surface. The similarity of these values a dis in environmental interpretation, but similarity is not necescary. Trends of faunal characters are nore applicable than fixed values; for example, increasing specific dominance and percentage of arenaceous Foraminifera combined with decreasing numbers of species and numbers of specimens indicate proximity to nearshore, brackish environs. The combination of the various faunal characters is important. Values for any ote character may not be sufficient for accurate interpretation, but complementary indications from several characters increase the accuracy considerably.

Rates of sedimentation and removal are factors which seldom remain constant. These factors, combined with post-depositional destruction of tests, should influence the resultant faunal characteristics. A consideration of the effects of these factors brings to mind several questions. Are marine transporting agents solective to a point of distinguishing between various species? Undoubtedly they are to a certain extent. Large chambered, thin-walled, unfilled specimens will be removed more readily than thick, small chambered or filled specimens of similar size. It is questionable, however, that similar-sized, ecfually preserved specimens of an area would offer varying resistance to transportation. Another question concerns the strength of the foraminiferal tests. Considerable force may be necessary to destroy a specimen when that specimen is cushioned by water, or by satursted unconsolidated sediment. 
Post-depositional destruction of foraminiferal tests does occur. Probably enough difference exists in the strength of various specific tests such that, over a period of time, most specimens of a fragle species will be destroyed while specimens of other more durable species are spared. Little correction can be made for this other than noting the amount of fragmental specimens and considering this in the interpretation. Familiarity with faunal assemblages and specific characteristics enable one to recognize, from fragments, most genera and some species, at least in recent faunas. In consideration of the physical factors acting on the foraminiferal faunas, 1t becomes necessary to record variations in properties which offer varying degrees of resistance to transportation. The amount of fragmental shell in a sample should also be noted. If 1 is is assumed that the species are not differentially affected by transportation and sedimentation, then specific dominance will not be appreciably influenced by changes in the rates of these factors. The percentage of arenaceous Foraminifera will not be affected by these changes except in the event that physical action destroys the fragile tests. Numbers of species and numbers of specimens, howover, are strongly influenced by variations in these factors. Increased terrigenous deposition decreases the number of epecimens by diluting the benthonic population. of a given sample. Numbers of species are affected in a similar manner by the masking of "rare" species. Increased transportation indiscriminately removes large numbers of specimens, and thus the benthonic population of a local ares is decreased. Numbers of species would also decrease since the fewer specimens of the "rare" species would soon be removed completely. $\varepsilon$ 
In this area the similar size, preservation, type of chambers, thickness of walls, and shape of the various species preclude selective removal. Fragments of arenaceous Foraminifera are very common in the Sound core samples. These fragments are the colled portions of specimens of the gerus Ammobaculites. L. salsus 1s, by far, the most common and $\underline{A}$. exiguus constitutes the remainder of the fragmental specimens. Fragnentation occurred possibly before the samples were collected or, more likely, during the laboratory washing process when a fine spray of water disaggregated the sample over a screen. Since fragmentation did not prevent specific identification it is believed that the faunal analysis is unappreciably affected.

Surface values determined for this area are sufficiently applicable to the core fauna to enable interpretation of the fann in each sample. Although the core faunal values, when averaged, are within the ranges of the surface values, enough differences exdst in this relatively short section to emphasize the need for determination of trends of faunal characters rather than, fixed values. Faunal characteristic values must be determined for each section in question and these values must be based on the known ranges in the section.

Environmental Interpretation of Core Foraminifera

On the basis of the faunal characters (specific conposition, specific dominance, numbers of species, numbers of specimens and percentage of arenaceous Foraminifera), the fauna of each sample is interpreted as indicative of either a brackish depositional environment (Sound type), an openmarine environment, a mixed environment (Pass type), or a marsh environnent (Figure 12). Those samples which are barren are interpreted as non-marine. 


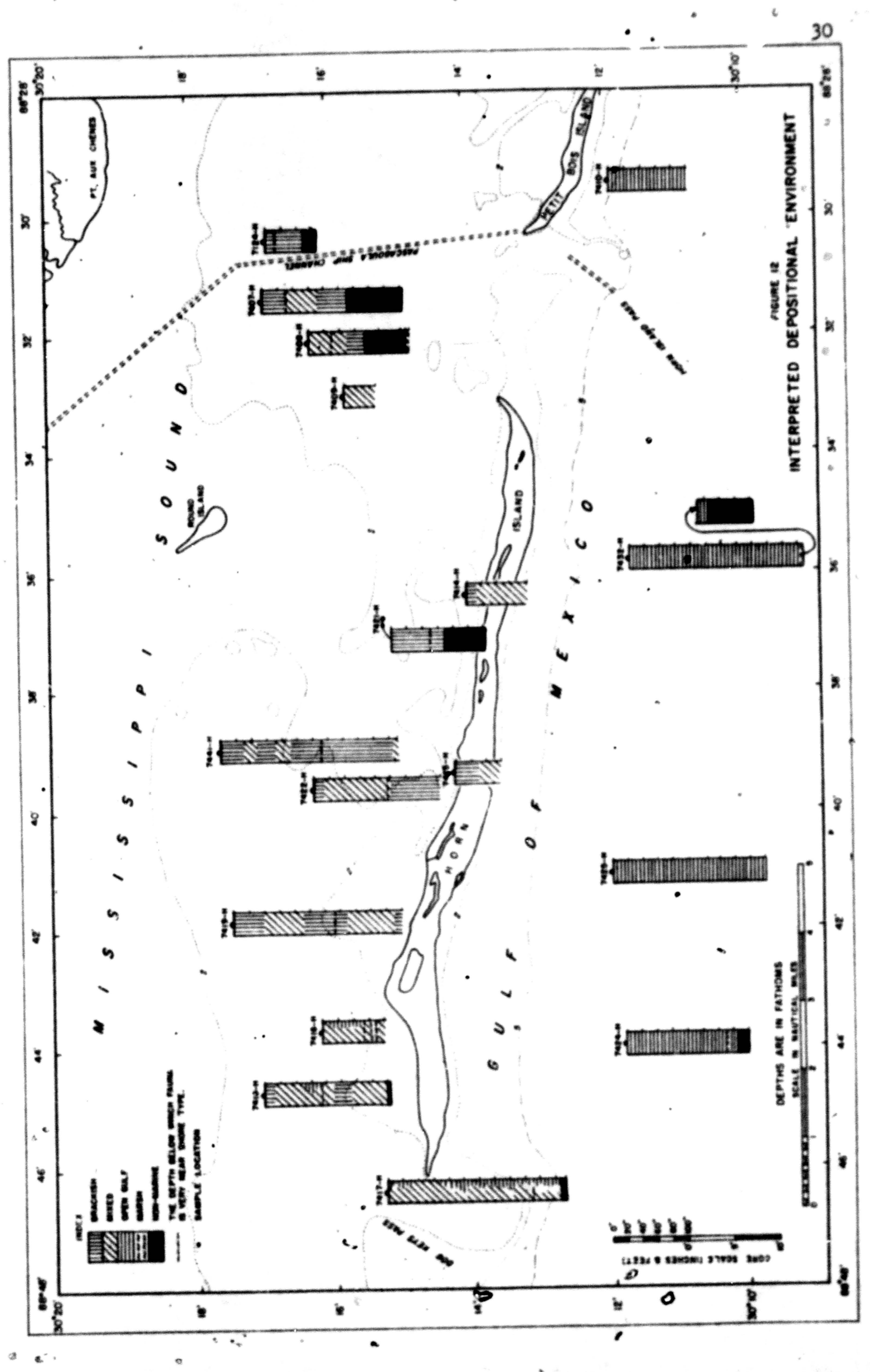


The open-gulf cores contain an open-marine fauna which varies only near the bottom as in cores $742 \mathrm{~L}-\mathrm{H}$ and $7432-\mathrm{H}$. A significant decrease in numbers of specimens and an increase in specific dominance indicate that nearshore, open-marine conditions existed during deposition of these lower samples. Ths distinction between the nearshore brackish and the nearshore marine fauna is based on the difference in arenaceous faunal content. A non-marine clay occurs below the nearshore marine level. Core $7425-\mathrm{B}$ does not penetrate the nearshore and non-marine horizons. This suggests the presence of a depression in the non-marine clay near core 7425-H. Core 7417-H, located in Dog Keys Pass, is composed almost entirely of a mixed environment fauna. Most of these samples contain a near open-marine fauna. The nearshore open-marine and the non-marine horizons can be recognized in this core. Nearshore brackish horizons can be recognized in most of the remaining cores.

In the Sound cores, the depositional environments are generally cyclic and change rather rapidly. Brackish and mixed environment indications alternate in most cores. This character of frequent change is significant. A marsh fauna is found in two cores, and the non-marine horizon is recognized in several. The non-marine samples in $7421-\mathrm{H}$ and 7408 -H differ from other non-marine samples in that the former are composed of clean quartz sand.

Marine influence was more extensive in the past over most of the present Sound area. More than one-third of the Sound cores fauna indicate brackish-marine mixing. Although a few samples contain a fauna indicative of near-marine environments, no open-marine fauna occurs in the Sound core samples. This indicates that a barrier existed early in 
the deposition of the Sound cores sediment. Possibly cores $74 \mathrm{LL}-\mathrm{H}$ and 7415-H would penetrate a very thin, nearshore, open-marine horizon if extended. The occasional occurrences of "near-marine" faunas, and the common occurrences of mixed enviranment faunas in the Sound cores indicate that the early barrier was not as continuous or as effective as it is at present.

The preceding interpretation does not require a knowledge of generic environmental significance. More detalled interpretation can be made by applying what is known of the environmental significance of the various genera. The surface fauna of the Spund is replaced, or appreciably supplemented, by Streblus and Iphidium. Nonionella and Buliminella are more abundant in the cores than they are at the surface. The cpengulf core fauna is supplemented by Hanzawaia and Rosalina. Recent studies (Parker, 1954) establish that, in the northeastern inf of Nexio, distributions of empty tests closely approximate distributions of living Foraminifera. Streblus and Blphidium are most abundant in a narrow zone about 5 to 15 miles off shore in water depths of about 10 fathoms or less. Salinity measurements vary from 26 to 30 parts per thousand in this wone. Nonionella and Buliminella are abundant in a broad belt extending from southeast of the present Mississippi Delta to an area east of the north end of the Chandeleur Islands. Phleger (1955) reports abundant living specimens in this area. Nonionella and Buliminella seem dependent on some factor of a "near-delta" environment. The alignment of these genera with the Mississippi Delta systen is unlikely coincideptal. The favorable factors of this environment are not known but, apparently, these genera require a less dilute marine environment than do Streblus and Blohidium 
which occur lancward of the Nonionella-Buliminella zone. Hanzawaia and Rosalina are abundant, over an extensive area on the continental shelf. In this area, water depths are approximately 10 to 30 fathoms and salinity 1s about 30 to 32 parts per thousand.

The increase in specinens of Streblus and Blphidium in the Sound cores and the increase in Hanzawaia and Fosalina in the open-gulf cores are correlated. Both increases are indicative of more marine conditions existing in the past. The increase in specimans of Nonionella and Buliminella within the cores indicates greater deltaic influence in the past.

Brief speculation on the history of core sediment deposition results in the following interpretation of the sequence of events in the area. At a time when sea level was lower, this area existed as an expoyed clay surface. A sand body of minor areal extent existed in the northeast quarter of the area. As sea level rose, open-merine depositicn occurred in the present open-gulf area. Horn Island was formed soon after the shoreline transgressed the present site of the 1sland. Nearshore, brackish deposition occufred in the present Sound area. The fluctuation from brackish to mixed environments, indicated by the Sound cores fauna, illustrates the variable character of this restricted area. The open-gulf environment was more uniform. A "near-delta" influence existed in the area early in the period of core sediment deposition. This influence is recorded in the lower sections of cores in the three environments. Late in the periog, the environment became less marine and the deltaic influerce diminished. Horn Island is now exerting its maximum effect as a barrier to marine invasion. Some explanation can be 
advanced for the various environmental changes. An increase in run-off from the Mississippi coast could dilute the marine water and thus extend brackish conditions seaward. The deltaic influence is thought to have been supplied by the St. Bernard subdelta and possibly its precursors. This subdelta is relatively inactive at present and has not discharged significant quantities of water for approximately 500 years (H. N. Fisk, 1955).

\section{Points Worthy of Future Bxamination}

A few 1deas that have come to mind, but that have not been examIned sufficlently, are worthy of mention. Thickness and ornamentation of calcareous tests are probable indicators of environment. It was noticed that size and thickness of calcareous tests were less in ihe brackish environment. The most ornate and thick-walled specimens of Streblus were found in a lake on Horn Island. The salinity was not measured but the water is salty to the taste. Chitinous linings occur in nost of the calcareous specimens of the brackish environment. In contrast, no chitinous linings were observed in specimens from the continental she If. Natural decalcification occure to some extert in the Sound.

Fecal pellets of a small worm are very abundant in the Sound. In some samples, these pellets are the dominant constituent of the sediment. Vegetative matter does not appear to be significant except in sone of the barren clay samples where pieces of wood are rather common. Wood also occurs in the marsh sample of core $7408-\mathrm{H}$. Diatoms are occasionally very abundant but no significance could be attached to their distributions. Pyrite, pyritized wood fibre, and pyrite-filled Foraminifera are rather comon in the area. 
An Interesting study could be directed toward the examination of morphology as related to environment. Perhaps colling and mode of test development is related to environment. 


\section{- $\quad \because$ conclusions}

1. Characteristies of modern foratiniferal distributions can be established such that ecologic application can be made to fossil assemblages. These characteristics are: specific composition, percentage of arenaceous Foraminifera, number of species, specific dominance, and numbers of specimens. Genera and species are environmentally controlled. Numbers of species and numbers of speoimens decrease in nearshore brack1sti and/or restricted areas. The percentage of arenaceous Foraminifera and the percentage occurrence of the dominant species increase in hearshore brackish and/or restricted areas.

2. The depositional environment of each core sample cañ be interpreted and the sequence of events in core sediment deposition concluded to be: lowering of sea level with non-marine clay and sand exposed; rise in sea level rasulting in nearshore marine deposition in the present open-gulf area, nearshore brackish deposition in the present Sound area, and the formation of a barrier island in essentially the same position as that now occupied by Horn Island; continued open-marine deposition in the present open-gulf area and alternating brackish and mixed environment deposition in the present Sound area; the existence of a "near-delta" influence upon the area throughout most of the depositional period; and, at present, the occurrence of a brackish Sound area, an effective barrier island, a dilute marine open-guif area, and a negiigible - deltaic influence upon the area. 
Bandy, Orville L., 1954, "Distribution of Some Shallow-water Foraminifora in the Northern Gulf of Mexico"; U. S. Qeol. Survey, Prof. Paper $254-\mathrm{F}$.

1956, "Bcology of Foraminifera in Northeastern Oulf of Mexico", U. S. Geol. Survey, Prof. Paper 274-0.

Cushman, Joseph A., 1922, "Shallow-water Foraminifera of the Tortugas. Region", Dept. Marine B101. Papers, vol. 17, Publ. no. 311, Carnegie Inst. Washington.

, 1926, "Recent Foraminifera from Porto Rico", 1b1d., vol. 23, Publ. no. 34, pp. 75-84.

1930a, "Pleistocene Foraminifera from Maryland", Cushman Lab. Foram. Research, Contr., vol. 6, pt. 4, pp. 94-100.

, 1930b, "Foraminifera of the Atlantic Ocean", Bull. U. S. Nat. Mas., no. 10h, pt. 7 .

and Parker, Frances L., 1937, "Notes on Some O1igocene Species of Bulimina and Buliminella", Cushman Lab. Foram. Research Contr., vol. 13, pt. 1, pp. 36-40.

, 1944, "Foraminifera from the New England Coast", Cushman Lab. Foram. Research, Spec. Publ. no. 12.

, 1947, "New Species and Varieties of Foraminifera from Off the Southeastern Coast of the United States", Cushman Lab. Foram. Research Contr., vol. 23, pts 4, pp. 86-91.

and Bronnimann, P., 1948, "Additional New Species of Arenaceous Foraminifera from Shallow Waters of Trinidad", 1bid., vol. 24 , pt. 2, pp. 37-4l.

Drydén, A. L., 1931, "Accuracy in Percentage Representation of Heavy Mineral Frequencies", Nat. Acad. Sc1., Pr., vol. 17, no. 5, pp. $233-238$.

BIIIs, Brooks F. and Messina, Angelina'R., 1940, "Catalogue of Foraminifera", Amer. Kus. Nat. Kist., Spéc. Publ.

Fisk, H. N., 1955, "Sand Facies of Recent Mississippi Delta Deposits", Compte Rundu, Third World Petroleum Congress, Rome, Italy.

Otto, G. H., 1933, "Comparative Tests of Several Methods of Sampling Heavy Mineral Concentrates", Jour. Sed. Petrolosys vol. 3, pp. 30-39. 

APPERIDIX

Identification of the Furaminifera is based largely on comarisons witn topotypes and homeotypes furnished by Frances L. Parker and Fred B Phleger. The remaining species were identified by comparisen with figured and described hypotypes. All figured specinens are flled in the foraminiferal collection of the Geology and Geochemistry Division of Gulf Research and Development Company. The following is an alphabeticalify arranged list of the most comon species. Only orlolnal references, references to name changes, and references to reports on related areas are included.

Ammobaculites exigurus Cushman and Bronnimann Plate 1, Figures $\mathrm{L}, \mathrm{B}$

19L8. Ammobaculites exdgus Cushman and Bronnimann, Cushman Lab. Foraz. Research Contr., vol. 24, pt. 2, p. 38, pl. 7, figs. 7, 8.

1953. Ammobaculites exiguus Cushman and Bronnimann. Parker, et ul., Cushman Found. Foram. Research, Spec. Publ. no. 2, p. 5, pl. 1, fig. 16. Recent Foran., Southwest Texas.

1954. Amhobaculites exlous Cushman and Bronnimann. Phleger, Am. Assoc. Petroleum Geol. Bull., vol. 38, no. 4, p. 633, pl. 1, f1g. 5. Recent Foram., Mississippi Sound.

1956. Ammobaculites exighus Cushman and Bronnimann. Bandy, U. S. Geol. Survey Prof. Paper 27L-G, p. 192, pl. 30, f1g. 2. Recent Foram., culf of Mexico.

Amnooaculites exiguus is usually less than 10 parcent of the Sound fauna but occasionaliy constitutes 22 percent of the fauna. It is usually less than 1 percent in the open gulf. It is less than 5 percent and essentially restricted to the Sound near Breton Sound (Phleger, 1955).

\section{Ammobaculites salsus Cushman and Bronnimann}

Plate I, Figures 2A, B

1948. Armobaculites salsas Cushman and Bronnimann, Cushman Lab. Foram. Research Contr., vol. 24, pt. 1, p. 16, p1. 3, 11gs. 7-9. Arenaceous Foram., Trinidad. 
1953. Amnobaculites salous Cushman and Bronnimann. Parker, et al., Cushman Found. Foram. Research, Spec. Publ. no. 2, p. 5, pl. 1, 11gs. 17-25. Recent Foram., Southwest Texas.

1954. Ammobaculites salsus Cushman and Bronnimann. Phleger, Am. Assoc. Petroleum deol. Bull., vol. 38, no. 4, p. 635, pl. 1, 11gs. 7, 8. Recent Foram., Mississipp1 Sound.

1956. Ammobaculites salsus Cushman and Bronnimann. Bandy, U. S. Geol. Survey Prof. Paper $274-0$, p. 192, pl. 30, fig. 4. Recent Foram., culf of Mexico.

Ammobaculites salsus is very abundant in the Mississippi Sound and essentially restricted to 1t. It is rare in the open gulf and abundant in the bays behind barrier islands off Texas (Parker, 1953). It is abundant in the bays and Breton Sound, and common in the marshes of the southeast Mississippi Delta (Phleger, 1955).

\section{Bigenerina irregularis Phleger and Parker}

Plate 1, Pigures $3 \mathrm{~A}, \mathrm{~B}$

1951. Bigenerina irregularis Phleger and Parker, Geol. Soc. Anerica Men., vol. L6, pt. 2, p1. I, f1gs. 16-21. Recent Foram., Northwest oulf of Maxico.

1954. Bigenerina irreqularis Phleger and Parker. Phleger, Am. Assoc. Petroleum Geol. Bull., vol. 38, no. 4, p. 636, pl. 1, Pigs. 16, 17. Recent Foram., Mississippi Sound.

1954. Bigenerina irreqularis Phleger and Parker. Parker, Harvard Coll. Yus. Comp. Zooli $\overline{\mathrm{y} \mathrm{BuIl}}$., v. III, no. 10, p. 492, pl. 3, 11fs. 1-3. Recent Foram., Northeastern oulf of Mexico.

1954. Bigenerina 1rreqular1s Phleger and Parker. Bandy, U. S. Ceol. Survey Prof. Paper 254-F, p. 135, pl. 29, figs. 8, 9. Recent Foram., Gulf of Mexdco.

Bigenerins irregularis is essentially restricted to the open gulf according to results of this study and usually comprises less than 10 percent of the fauna. It usually constitutes 5 to 10 percent of the fauna off the Texas bays (Parker, et al., 1953). It is essentially restricted to the offshore, open-gulf area near the southeast Mississippi Delta arsa (Phleger, 1955).

Bolivina lowmani Phleger and Parker Plate 1, Figures LA,B

1951. Bolivina lowmant Phleger and Parker, Geol. Soc. America Nen., vol. 46, pt. 2, p. 13, pl. 6, S1gs. 20A, B, 21. Recent Foran., Northwestern Oulf of Mexico.

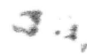


1953. Bolivina lowman1 Phleger and Parksr. Parker, et al., Cushman Found. Foram. Research, Spec. Rabl. no. 2, p. 6, pl. 4, 1 ig. 1. Recent Foram., Southwest Texas.

1954. Bolivina lowmani Phleger and Parker. Phleger, Am. Assoc. PetroIeum Geol. Bull., vol. 38, no. 4, p. 637, pl. 1, figs. 18, 19. Recent Foram., Mississippi Sound.

1954. Bolivina lowmani Phleger and Parker. Parker, Harvard Coll. Mus. Comp. Zoology Bull., v. III, no. 10, p. 515, p1. T, f1g. 21. Recent Foram., Northeastern Gulf of Mexico.

Bolivina lowmani occurs mostly in the open gulf according to this study and usually constitutes a mall percentage of the fauna.

Bolivina pulchella primitiva Cushman

$$
\text { Plate I, Figures } 5 A, B \text {, }
$$

1930. Bolivina pulchella (d'Orbigny) var. primitiva Cushman, C fide Florida state Gecl. Survey Bull.; vol. L, p. 47, pl. 8, figs. 12A, B. 7

1953. Bolivina pulchella primitiva Cushman. Parker, et al., Cushnan Found. Foram. Research, Spec. Publ. no. 2, p. 6, pl. 4, figs. $4,5$. Recent Foram., Southwest Texas.

1954. Bolivina pulchello (d'Orbigny) var. prinitiva Cushman. Phileger, Am. Assoc. Petroleum Geol. Bull., vol. 38, no. 4, p. 637, pl. 1, fig. 20. Recent Foram., Mississippi Sound.

1954. Bolivina pulchella primitiva Cushman. Parker, Harvard Coll. Mus. Comp. Zoology Bul1., v. III, no. 10, p. 516, pl. 7, fig. 36. Recent Foram., Northeastern Gulf of Mexico.

\section{Bolivina striatula Cushran}

$$
\text { Plate 1, Figures 6A, B }
$$

1922. Bolivina striatula Cushman, Carnegie Inst. Washington, Publ. no. 311, (Dept. Marine Biol., Papers, vol. 17), p. 27, pl. 3, fig. 10. Shallow Water Foram., Tortugas.

1953. Bolivina striatula Cushman. Parker, et al., Cushman Found. Foram. Research, Spec. Publ. no. 2, p. 6, pl. 4, figs. 4, 5. Recent Foram., Southwest Texas.

1954. Bolivina atriatula Cushman. Phleger, Am. Assoc. Petroleum Geol. Bull., v. 38, no. 4, p. 637, Recent Foram., Mississippi Sound.

1954. Bolivina striatula Cushman. Bandy, U. S. Geol. Survey Prof. Paper 25L-F, p. 135, pI. 31, fig. 9. Foram., Gulf of Nexico. 
Buccella hannai (Phleger and Parker)

Plate I, Figures 7A, B,C

1951. Boonides hannal Phleger and Parker, Geol. Soc. America Mem., vi. 46, pt. 2, p. 21, pl. 10, figs. 11A,B, 13A,B, $\mathrm{H}_{4} \mathrm{~A}, \mathrm{~B}$.

Recent Foram., Northwest Culf of Mexico.

1952. Buccella hamai (Phleger and Parker), Bmend. Cfide Andersen, Washington Acad. Sc1. Jour., Baltimore, Md., vol. 42, no. 5, p. 14h, 147, text f1g. 3A, B, C.7 Buccella, New Rotalid Foram. Genus.

1954. Buccella hannal (Phleger and Parker), Phleger, Am. Assoc. Petroleum Geol. Bull., vol. 38, no. 4, p. 637, pl. 2, 11gs. 13, W. Recent Foram., Mississippi Sound.

1954. Buccella hannal (Phleger and Parker). Parker, Harvard Coll. Mus. Comp. 200 I0 Bull., v. III, no. 20, p. 530, pl. 9, 11gs. 25, 26. Recent Forar., Nor theastern Gulf of Vexico.

Buccella hanial occurs rather commonly in the open gulf at a frequency of less than 5 percent. It is essentially restricted to the open gulf.

\section{Buliminella bassendorfensis Cushman and Parker \\ Plate 1, Figures $8 \mathrm{~A}, \mathrm{~B}$}

1937. Buliminella bassendorfensis Cushman and Parker, Cushman Lab. Foran. Research Contr., vol. 13, pt. 1, p. 40, pl. 4, figs. 13h, B. Oligocene Bulimina and Buliminella.

1953. Buliminella sp. cf. B. bassendorfensis tushman and Parker. Parker, t al., Cushman Found. Foram. Research, Spec. Publ. no., 2, p. 6, pl. 4, figs. 6, 7. Recent Forat., Southwest Texas.

1954. Buliminella bassendorfensis Cushman and Parker. Phleger, Am. Assoc. Petroleum Geol. Bull., vol. 38, no. 4, p. 637, pl. 1, 11gs. 22, 23. Recent Foram., Mississippi Sound.

1954. Buliminella bassendorfensis Cushman and Parker. Parker, harvard Coll. Kus. Comp. Zoology Bull., v. III, no. 10, p. 509, pl. 6, fig. 13, Recent Foram., Nor theastern Culf of Mexico.

\section{Bulininelle elegantissima (d'Orbigny)}

$$
\text { Plate l, Figures } 9 \mathrm{~A}, \mathrm{~B}
$$

1839. Bulimina elegantissima d'Orbigny, [fide Voy. Amer. Werid., vol. 5, pt. 5, "Porandififeres." p. 51, pi. 7, 11 gs. 13, 14.7

1911. Buliminella elegantissima (d'Orbigny) Cusbnan, Cfide U. S. Nat. Tus. Bull., 71, pt. 2, p. 88.7 Genotype of Buliminella. 
1933. Bulimineila elegantissima (d'Orbigny). Cfide Cushman and Cahill, U. E. Geol. Survey, Prof. Paper $175-\Lambda$, p. 23.7 Miocene Foram., Bastern U. 8. Coastal Plain.

1944. Buliminella elegantissima (d'Orbigny). Cushman, Cushman Lab. Foram. Research, Spec. Pub1., no. 12, p. 27, pl. 3, f1gs. 43, 44. Recent Foram., New Ingland.

1953. Buliminella elegantissima (d.Orbigny). Parker, et al., Cushman Found. Foram. Research, Spec. Publ. no. 2, p. 6, pl. 4, 11gs. 8, 9. Recent Forams., Southwest Texas.

1954. Buliminella elegantissima (d'Orbigny). Phleger, As. Assoc. Petroleum Geol. Bull., vol. 38, no. 4, p. 637, p1. 1, f1gs. 24, 25. Recent Foram., Mississippi Sound.

1955. Buliminelle elegantissima (d'Orbigny). Walton, Jour. Paleontology Bull., v. 29 , no. 6, p. 1004, pl. 102, fig. 17. Living Foram., Baja, California.

Buliminella elexantissima is rather common in the open gulf as

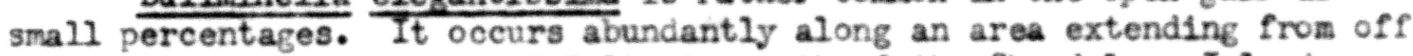
southeast of the :ississippi Delta to north of the Chandeleur Islands.

Slpridium munter1 Cole

Plate I, Figures 10A, B

1931. Blphidium gunteri Cole, [f1de Florida State leol. Survey Bull. 6, p. 34, p.. 4, figs. 9, 10.7 PIIocene and Pleistocene Foram., Florida.

1951. Etphidium gunteri Cole var. galvestonensis Kornfeld (Part), Fefie Stanford University Dept. Geology Contr., vol. 1; no. 3, p. 87, pl. 15, figs. 2A,B, 3A,B (not figrues $\mathrm{A}, \mathrm{B}) .7$ Recent Littoral, Texas and Louisiana.

1953. Blphidium gunteri Cole. Parker, et al., Cushman Found. Foram. Research, Spec. Publ. no. 2, p. 8, pl. 3, f1gs. 1\%, 19. Recent Foram., Southwest Texas.

1954. Bohidium gunter1 Cole. Phleger, Am. Assoc. Petroleum Geol. Bull., vol. 38, no. 4, p. 639, pl. 2, figs. 3, 4. Mecent Foram., Mississippi Sound.

1954. Blphidium gunteri Cole. Parker, Harvard Coll. Mus. Zoology Bull., v. III, no. 10, p. 508, pl. 6, 18. 16. Recent Foran., Northeastern oulf of Mexico.

1956. Blphidium gunteri Cole. Bandy, U. S. Gecl, Survey Prof. Paper 274-0, p. 194, pl. 30, flgs. 19A, B. Foram. Bcology, Northeastern Oulf of. Viexico. 
Bohidium gunteri is common to abundant in the passes and.open gulf according to this study. It occurs as small percentages in the Sound. It is abundant in the bays along the Texas coast (Parker, et al., 1953). It occurs abundantly in both the open-gulf and. Breton Sound areas (Phleger, 1955). It occurs commonly over much of the northeastern Gulf but the area of reatest abundance is about 5 fathoms or less.

\section{Elphidium incertum mexicanum Kornfeld PIate 1, Figures IIA, $B$}

1931. Blphidium incertum (Williamson) var. mexicana Kornfeld, C fide Stanford University Dept. Geology, Contr., vol. 1, no. 3, p. 89, pl. 16, figs. 1A,B, 2A,B.7 Recent Foram., Texas.

1953. Elphidium incertum mexicanum Kornfeld. Parker, et al., Cushman Found. For am. Research, Spec. Publ. no. 2, p. 8, pl. 3, 11gs. 20, 21. Recent Foran., Southwest Texas.

1952. Blphidium incertum mexicanum Kornield. Phleger, Am. Assoc. PatroIeum Geol. Bull., vol. 38, no. L, p. 639, pl. 2, f1gs. 5, 6. Recent Foram., Mississippi Sound.

1956. Blphidium mexicanum Kornfeld. Bandy, U. S. Geol. Survey Prof. Paper 274-G, p. 194, pl. 30, f1g. 20. Foram. Bcology, Northeastern Gulf of Nexico.

Blphidium incertum mexicanum occurs as small percentages. over most of the Blohidium sunteri distribution. It is rather common alone the beaches of St. Joseph and Matagorda Islands (Parker, et al., 1953). It occurs as small percentages in both Breton Sound and the open gulf (Phleger, 1955).

Elphidium sp. cf. E. koeboeense Leroy PIate 1, P1ğures 12A,B

1939. Elphidium koeboeense Leroy, [ fide Natuurk. Tijdschr. Nederl.Indie, dl. 99 , dfl. 8, p. 24.0, pl. 9, figs. 6, 7.7

1953. Elphidium sp. cf. ‥ koeboeense Leroy. Parker, et al., Cushnan Found. Research, Spec. Publ. no. 2, p. 8, pl. 3, figs. 22-23. Recent Foram., Southwest Texas.

Elohidium sp. cf. . koeboeense occurs as small percentages over most of the Blohidium distribution. It is rathor common in Mesquite Bay, Texas (Parker, et al., 1953). 


\section{Blphidium matagordarum (Korreleld)} Plate I, Figures 13A,B

1931. Nonion depressula (Walker and Jacob) var. matagordanum Kornfeld, [fide Stanford Univ., Dept. Geolog Contr., vol. 1, no. 3, p. 87, pl. 13, figs. 2A,B.7 Recent, Littoral. Texas and Loulsiana.

1953. Blphidium matagordamum (Kornfeld). Parker, in Parker, et al., Cushman Found. Foram. Research, Spec. Publ. no. 2, p. 8, pl. 3, f1gs. 2h, 25. Recent Foram., Southwest Texas.

1954. Elphidium matagordanum (Kornfeld). Phleger, Am. Assoc. Petroleum Geol. Bull., vol. 38, no. 4, p. 639, pl. 2, f1g. 7. Recent Foram., Mississippi Sound.

Blphidium matagordanum ocnurs as small percentages over most of the Blphidium distribution. It is rather common in the bays along the Texas coast (Parker, et al., 1953) and in Breton Sound (Phleger, 1955).

\section{Elphidium poexenum (d'Orb1gny)}

$$
\text { Plate I, Figures Ilu, B }
$$

1839. Polystomella poeyana d'Orb1gny, [fide in De la Sagra, H1st. Phys. Pol. Nat. Cuba, "Foraminiferes", p. 55, p1. 6, 11gs. 25, 26.7

1928. ? Elphidium poeyanum (d'Orblgny) Oushman, Cushman Lab. Foram. Research, Spec. Publ. no. 1, p. 205.

1930. Blohidium poeyanum (d'Orbigny). Oushman, U. S. Nat. Mas. Bull., 104, pt. 7, p. 25, pl. 10, f1ge. 4, 5. Recent Foram., Atlantic Ocean.

1953. Blphidium poeyanum (d'Orbieny). Parker, et al., Cushman Found. Foram. Research, Spec. Publ. no. 2, p. 9, pl. 3, 11g. 26. Recent Foran., Southwest Texas.

1954. Blphidium poeyanum (d'Osoleny). Phlezer, An. Assoc. Petroleum Geol. Bull., vol. 38, no. 4, p. 639, pl. 2, f1.s. 8, 9. Recent Foram., Mississippi Sound.

1954. Elphidium poeyanum (d'Orbigny). Parker, Harvard Coll. Mus. Comp. Z0010gy BuII., vol. III, no. 10, p. 509, pl. 6, fig. 17. Recent Foram., Northeastern Oulf of Mexico.

Blphidium poeyanum cccurs as small percentages over most of the Blphidium distribution. It is rather comon in both bays and open gulf along the Texas coast (Parker, et al., 1953) and in the rixed environnent of Breton Sound and the open gulf (Phleger, 1955). 


\section{Boistominella vitrea Parker Plate 1, Figures 15A, B, C}

1953. Bo1stominella vitrea Parker, in Parker, et a.., Cúshman Found. Foram. Research, Spec. Pub1. no. 2, p. 9, pl. 4, figs. 34-36, 40, 41. Recent Foran., Southwest Texas.

2954. Esistominella vitrea Parker. Phleger, Am. Assoc. Petroleum Geol. Bull., vol. 38 , no. 4, p. 639, p1. 2, f1gs. 11, 12. 'Recent Foran., Mississippi Sound.

1954. Bo1stominella vitrea Parker. Parker, Harvard Coll. Wus. Corp. Zoology Bnll., vol. III, no. 10, p. 534, p1. 10, 11gs. $20,26$. Recent Foram., Northeastern Gulf of Nexico.

Boistominella v1trea occurs as small percentages in the open gulf. It is abundant southeast of the Mississipp1 Delta (Phleger, 1955) and very common along the shelf-edge in the northeastern culf.

\section{Qaudryina exil1s Cushman and Bronnimann} Plate I, Figures 16A, B

1948. Gaudrylna exilis Cushman and Bronnimann, Cushnan Lab. Foram. Researen Contr., vol. 24, pt. 2, p. LO, pl. 7, flgs. 15, 16. Arenaceous Foram., Trinidad.

1953. Caudryina ex1l1s Cushman and Bronnimann. Parker, et al., Cushman Found. Foram. Research, Spec. Publ. no. 2, p. 9, pl. 1, P1gs. 37, 38. Recent Forams., Scuthwest Texas.

195L. Gaudryina exil1s Cushman and Bronnimann. Phleger, Am. Assoc. Petroleum Geol. Bull., vol. 38, no. 4, p. 639, pl. 2, f1g. 16. Recent Foram., Mississippi Sound.

\section{Guttulina australis d'Orbigny}

Plate I, Pigures 17A, B

1839. Guttulana (globulina) australis d'Orbigy, Cf1de Voyage, dans I' Amerique Meridionale; Foraminiferes. Strasbourg, Prance, LeVrault, tome 5, pt. 5, p. 60, pl. i, 11gs. 1-4.7

1870. Polymorphina regina Brady, Parker and Jones, [ flde Linnean Soc. Trans., vol. 27, p. 2Ll, pl. 41 , fig. 32.7

1930. Guttulina reglna (Brady, Parker anc Jones) Cushman and Ozawa, [ flde U. S. Nat. Fus. Proc., vol. 77, art. 6, p. 34, pl.6, P'igs. 1, 2.7

1953. Guttulina australis (d'Orbigny). Parker, et al., Cushran Found. Foram. lesearch, Spec. Publ. no. 2, p. 9, pl. 3, figs. 9, 10. Recent Foran., Southwest Texhs. 
1954. Guttulina austrelis (d'Orbigny). Thleger, Am. Assoc. Petroleum Geo1. Bull., vol. 38, no. 4, p. 639, p1. 2, 11g. 15. Recent Foram., Mis sis sippi Sound.

1954. Outtulinf austizalis (Brady, Parker afid Jones) Cuehman and Ozawa. Bandy, U. S. Geol. Survey Prof. Paper 25L-F, p. 136, p1. 29, fig. $T$. Foran., Gulf of Mexico.

1956. Guttulina australis (d'Ortigny). Bandy, U. S. Seol. Survey Prof. Paper 274-G, p. 194. Foram. Bcology, Nor theastern Oulf of Nexico.

Guttulina australls occurs rather commonly in the ofen gulf at frequencies of 5 percent or less.

Hanzawa1a strattoni (Applin)

Plate 1, Figures 18A,B, C

1925. Truncatulina americana Cishman var. strattoni Applin, Am. Assoc. Petroleum Geol. Bull., vo:. 9, no. 1, p. 99, pl. 3, f1g. 3, Miocene Foram., Loulsiara.

1931. Cibicides americana (Cushnan) var. strattoni (Applin) Kornfeld, Efide Stanford Univ., Dept. Ceolcg Contr., vol. 1, no. 3, p. 82.7 Checklist Recent, Texas Coastal Region.

1951. Cibicides concentricus (Cushman). Phleger and Parker, Geol. Soc.

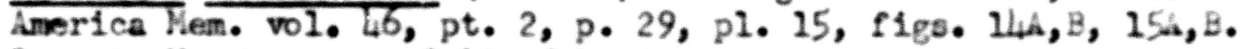
Recent, Nor thwestern culf of Kexdoo.

[non] Truncatulina concentrica Cushman, 1918, U. S. Geol. Survey Bull., no. 676, p. 6h, pl. 21, flg. 3 .

1953. Cibicidina strattoni (Applin) Parker, in Parker, et al., Cushman Found. Foram. Research, Spec. Publ. no. 2, p. 7, pl. 4, f1gs. 38, 39. Recent Foram., Southwest Texas.

1954. Cibicidina strattoni (Applin). Parker, Harvard Coll. Mus. Corp. 20010gy Bu11., vo1. III, no. 10, p. 544, p1. 13, figs. 8, 11. Recent Foram., Northeastern Gulf of Nexico.

1954. Ciblcidina strattoni (Applin). Phleger, An. Assoc. Petroleum Geol. Bull. vol. 38, no. 4, p. 638, pl. 1, f1gs. 26, 27. Recent Foram., Mississippi Sound.

1954. Hanzawa1a strattoni (Applin) Bandy, U. S. Geol. Survey Prof. Paper 25L-F, p. 136, p1. 31, fig. 4. Recent Foran., Gulf of Kexjco.

Hanzawala strattoni is abundant in the open greff and usually constitutes 10 percent or more of the fauna. It dominates the fauna of most samples on the continental shelf of the nor theastern oulf of Nexico. It occurs as small percentages in the bays along the Texas coast and more abundantly in the open gulf (Parker, et al., 1953). 


\section{Nonionella atlantica Cushman}

\section{Plate 1, Figures 19A,B,C}

1947. Nonionella atlantica Cushman, Cushman Lab. Foram. Research Contr., vol. 23, pt. 4, p. 90, pl. 20, figs. 4, 5. Foram., Coastal

Southeast U. S.

1953. Nonionella atlantica Cushman. Parker, et al., Cushman Found. Foram. Research, Spec. Publ. no. 2, p. 1l, pl. 3, figs. 30, 31. Recent Foram., Southwest Texas.

1354. Nonionella atlantica Cushman. Phleger, Am. Assoc. Petroleum Geol. Bull., vol. 38, no. 4, p. 642, pl. 2, figs. 25, 26. Recent Foram., Mississippri Sound.

1954. Nonionella atlantica Cushman. Parker, Harvard Coll. Mus. Comp. Zoology, Bull., vol. III, no. 10, p. 567, pl. 6, figs. 6, 7. Recent Foram., Northeastern Culf of Mexico.

1954. Nonionella atlantica Cushman. Bandy, U. S. Geol. Survey Prof. saper 254-F, p. 137, pl. 29, fig. 10. Foram., Gulf of Mexico.

Nonionella atlantica is very rare in Mississippi Sound. It is rather common as small percentages in the open gulf according to this study and off Texas (Parker, et al., 1953). It is rather common in the Nonionella zone east of the delta system.

\section{Nonionella opima Cushman}

$$
\text { Plate I, Figures COA,B,C }
$$

1947. Nonionella opima Cushman, Cushman Lab. Foram. Research, vol. 23, pt. 4, p. 90, pI. 20, figs. 1-3. Foram., Coastal Southeast U.S.

1953. Nonionella opima Cushman. Parker, et al., Cushman Found. Foram. Research, Spec. Publ. no. 2, p. 11, pl. 3, figs. 32, 33. Recent Foram., Southwest Texas.

1954. Nonionella opima Cushman. Phleger, Am. Assoc. Petroleum Geol. Eull., vol. 38, no. 4, p. 642, pl. 2, figs. 27-29. Recent Foram., Mississippi Sound.

1954. Nonionella opima Cushman. Parker, Harvard Coll. Mus. Comp. Zoology Bull., vol. III, no. 10, p. 507, pl. 6, figs. 10-12. Recent Foram., Northeastern Gulf of Mexicon

Nontonella opima is distributed in essentially the same manner as N. atlantica. N. opima dominates the fauna of the Nonionella zothe which extends from southeast of the Mississippi Delta to east of the north end
of the Chandeleur Inlands. 


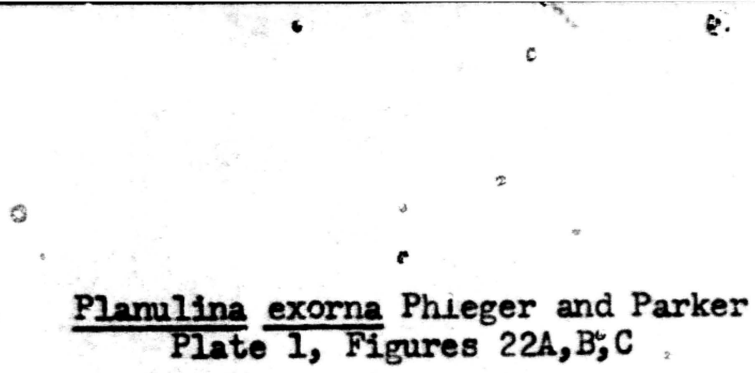

1951. Planulina exorna Phleger and Parker, Geol. Soc. America Mem., Vol. $46 ;$ pt. 2, p. 32 , pl. 18, figs. $5 \mathrm{~A}, \mathrm{~B}, 6 \mathrm{~A}, \mathrm{~B}, 7 \mathrm{~A}, \mathrm{~B}, 3 \mathrm{~A}, \mathrm{~B}$. Foram., Northwestern Culf of Mexico.

1954. Planulina exorne Phleger and Parker. Parker, Harvard Coll. Mus. Comp. Zoology Bull., vol. III, no. 10, p. 540, pl. 1l, figs. 28, 29. Recent Foram., Northeastern Gulf of Mexico.

1955. Planulina exorna Phleger and Parker. Walton, Jour. Paleontology Bull., vol. 29, no. 6, p. 1011, pl. 104, figs. 24, 25, 29, 30. Living Foram., Baja, California.

\section{Quinqueloculina compta Cushman .} Plate 2, Figures 1A,B,C

1947. Quinqueloculina cometa Cushman, Cushman Lab. Foram. Reseárch Contr., vol. 23, pt. 4, p. 87, pl. 19, fig. 2. Foram., Southeastern Ccastal U. S.

1953. Quinqueloculina compta Cushman. Parker, et al., Cushman Found. Foram. Research, Spec. Publ. no. 2, p. 12, pl. 2, figs. 5, 6. Recent Foram., Southwest Texas.

1954. Quinqueloculina compta Cushmafi. Phleger, Am. Assoc. Petroleum Geol. Bull., vol. 38, nó. 4, p. 643, pl. 2, fig. 36. Recent Foram. gississippi Sound.

1954. Quingueloculina cormta Cushman. Parker, Harvard Coll. Hus. Comp. Zo0logy Bull., vol. III, no. 10, p. 496, Fl. 3, figs. 20, 27. Recent Foram., Northeastern Gulf of Mexico.

1954. Quinqueloculina compta Cushman. Bandy, U. S. Geol. Survey Prof. Paper 254-F, p. 138, pl. 28, fig. 2. Recent Foram., Gulf of Mexico.

1956. Quinqueloculina compta Cushman. Bandy, U. S. Geol. Survey Prof. Paper 274-G, p. 196, pl. 29, fig. 5. Foram. Bcology, Gulf of Mexico.

Quingueloculina compta is rather common as small percentages in the open gulf. It commonly occurs on the beaches and occasionalily in the bays and open gulf off Texas (Parker, et al., 1953).

\section{Quinqueloculina lamarckiana deOrbigny Pláte 2, Figures $2 \mathrm{~A}, \mathrm{~B}, \mathrm{C}$}

1839. Quinqueloculina lamarckiana d'Orbigny, [fide in De Ia Sagra, Hist. Phys. Pol. Nat. Cuba, FForaminiferes", p. 189, pl. 11, figs. 14, 15.7 
1953. "Quinqueloculina lamarckiana d'Orbigny. Parker, et al., Cushman Found. Foram. Research, Spec. Publ. no. 2, p. 12, pl. 2, figs. 11, 12. Recent Foram., Southwest Texas.

1954. Quinqueloculina lamarckians d'Orbigny. Parker, Harvard Coll. Mus. Comp. Zoology Bull., vol. III, no. 10, p. 497, pl. 4, figs. 5, 6. Recent Forams., Northeastern Guif of Mexico.

1954. Quinqueloculina lamarckiana d'Orbigny. Bandy, U. S. Geol. Survey Prof. Paper 254-F, p. 138, pl. 28; fig. 3. Recent Foram., Gulf of Mexico.

Quingueloculina lamarckiana is rather common as small percentages in the open gulf according to this study and off Texas (Parker, et al., 1953).

\section{Quinqueloculina poevana d'Orbigny \\ Plate 2, Figures $3 \mathrm{~A}, \mathrm{~B}, \mathrm{C}$}

1839. Quinqueloculina poeyana d'Orbigny, [ fide in De la Sagra, Hist. Phys. Pol. Nat. Cuba, "Foraminiferes", p. 191, pl. 11, figs. 25-27.7

1953. Quinqueloculina poeyana d'Orbigný. Parker, et al., Cushman Found. Foram. Research, Spec. Publ. no. 2, p. 12, pl. 2, figs. 13, 4. Recent Foram., Southwest Texas.

1956. Quingueloculina poeyana d'Orbigny. Bandy, U. S. Geol. Survey Prof. Paper 27L-G, p. 196, pl. 29, fig. 6. Foram. Bcology, Northeastern Gulf of Mexico.

Quinqueloculina poexana occurs occasionally as small percentages in the open gulf according to this study and in the bays of Texas (Parker, et al., 1953).

\section{Quinqueloculina seminula (Linné)}

$$
\text { - Plate 2, Figures } 4 \mathrm{~A}, \mathrm{~B}, \mathrm{C}
$$

1767. Serpula seminulum Iinné, [ fide Syst. Nat., ed. 12, p. 1264.]

1826. Quingueloculina seminula (Iinné) d'Orbigny, C fide Ann. Sci. Bat., vol. $7 ;$ p. 303.7\%

1944. Quinqueloculina seininula (Linné). Cushman, Cushman Lab. Foram. Research, Spec. Publ. no. 12, p. 13, pl. 2, fig. 14.

1953. Quinqueloculina seminula (Linné). Parker, et al., Cushman Found. Spec. Publ. no. 2, j. 12, pl. 2, figs. 18, 19. Recent Foram., Southwest Texas.

Quinqueloculina seminula occurs occasionally as small perçentages in the open gulf according to this study and is common to abundant along the south beaches of the islands off Texas (Parker, et al., 1953). 
Rosalina bertheloti d'Orbigny

Plate 2, Figures 5A,B,C

1839. Rosalina berthelot1 d'Orbigny, [ fide in Barker-Wêbb and Berthelot, Hist. Nat., Iles"Canaries, vol. 2, pt. 2, "Foraminiferes", p. 135 , pl. 1 , figs. 28-30 (as R. berthelotiana in plates.) 7

1954. Rosalina bertheloti d'Orbigny. Parker, Harvard Coll. Mus. Comp. Zoology Bull., vol. III, no. 10, p. 523, pl. 8, figs. 22, 23. Receint Foram., Northeastern Gulf of Mexico.

1956. non Hanzawaia bertheloti (d'Orbigny), Bandy, U. S. Geol. Survey Prof. Paper 27h-G, p. 195, pl. 31, fig. 6. Foram. Ecólogy, Northeastern Gulf of Hexico.

Rosalina bertheloti occurs commonly as small percentages in the open gulf of this study.

\section{Rosalina concinna (H. B. Brady)}

Plate 2, Figures $6 \mathrm{~A}, \mathrm{~B}, \mathrm{C}$

1884. Discorbina concinna H. B. Brady, Cfide Rept. Voy. Challenger, Zoology, vol. 9, p. 646, pl. 90, figs. 7, 8.7

1948. Rosalina d'Orbigny, Emerid. Brotzen, [fide Sweden, Sver. Geol. Unders.Arh., Stockholm, Ser. C, no. 493 (Arsb. 42, no. 2), p. 72, tf. 19.7

1954. Rosalina concinna (H. B. Brady). Parker, Harvard Coll. Mus. Comp. Zoology Bull., vol. III, no. 10, p. 524, pl. 8, figs. $17,18$. Recent Foram., Northeastern Gulf of Mexico.

1956. Discorbis concinmus (H. B. Bracy). Bandy, U. S. Geol. Survey Prof. Paper 27L-G, p. 193, pl. 3l, fig. 4. Foram. Ecology, Northeastern Gulf of Mexico.

Rosalina concinna is common in the open gulf and constitutes about 5 percent of the fauna. It is very abundant over the central shelf where it co-dominates the fauna with Hanzawaia strattoni.

Rosalina floridana (Cushman)

Plate 2, Fisgures $7 \mathrm{~A}, \mathrm{~B}, \mathrm{C}$

1922. Discorbis floridanus Cushman, Carnegie Inst. Washington, Publ. no. 311 (Dept. Maríne Biol., Papers, vol. 17), p. 39, pl. 5, figs. 11, 12. Shall ow-water Foram., Tortugas.

1948. Rosalina d'Orbigny, emend. Brotzen, [fide Sweden, Sver. Geol. Unders._A th., Stockholin, Ser. C, no. 493 (Arsb. 42, no. 2), p. 72, tf. 19.7 
1953. Discorbis floridana Gishman. Parker, et ai., Cushman Found. Foram. Research, Spec. Publ. no. 2, p. 7, pl. 4, figs. 18, 19. Recent Foram., Southwest Texas.

1954. Rosalina floridana (Cushman). Parker, Harvard Coll. Mas. Comp. Z00logy BuIl., v01. III, no. 10, p. 524, pl. 8, figs.: 19, 20. Recent Foram., Northeastern Gulf of Mexico.

1954. Discorbis floridanus Cushman. Bandy, U. S. Geol. Survey Prof. Paper 254-F, p. 136, pl. 31, fig. 1. Recent Foram., Gulf of Mexico.

1954. Discorbis moridanus Cushman. Phleger, Am. Assoc. Petroleum Geol. Bull., vol. 38, no. 4, p. 638, pl. 1, figs. 30, 33, 34. Recent Foram., Mississipp1 Sound.

Rosalina floridana is common as small percentages in the open gulf according to this study and the open gulf, beaches, and bays off Texas (Parker, et al., 1953).

$$
\frac{\text { Rosalina }}{\text { Plate 2, }} \frac{\text { suezensis }}{\text { Figures } 8 \mathrm{~A}, \mathrm{~B}, \mathrm{C}}
$$

1948. Rosalina d'Orbigny, emend. Brotzen, [fide Swedeh, Sver. Geol. Unders. Ath., Stockholm, Ser. C, no. 493 (Arsb. 42, no. 2), p. 72 , tf. 19]

1949. Discorbis suezensis Said, Cushman Lab. Foram. Research, Spec. Publ. no. 26, p. 36, pl. 3, fig. 34. Eoram., Northern Red Sea.

1954. Rosalina suezensis (Said). Parker, Harvard Coll. Mus. Comp. Zoology Bulli., vol. III, no. 10, p. 525, pl. 8, figs. 21; 26, 27 . Recent Foram., Northeastern Gulf of Mexico.

Rosalina suezensis is rather common in the open gulf of this area but is more common on the central shelf.

\section{Streblus beccarii (Linne) var. sobrimus (Shupack)}

$$
\text { Plate 2, Figures } 9 \mathrm{~A}, \overline{B, C}
$$

1930. Rotalia beccarii (Linn\$) var. parkinsoniana (d'Orbigny) Cushman, in Cushman Lab. Foram. Research, vol. VI, pt. 4, p. 100, pl. XIII, figs. llf-C. Pleistocene Foram., Maryland.

1934. Rotalia beccarii (Iinne) var. sobrina Shupack, Cfide Am. Mus. Nat. Hist., Novitiates, New York, N. Y., no. 737, p. 6, pl. opp. p. 9, figs. $4 \mathrm{~A}-\mathrm{C} .7$ Recent and Pleistocene Foram., N. Y. Harbor.

1953. "Rotalia" beccaril (Iinné) variant A. Parker, et al., Cushman Fourd. Foram. Research, Spec. Publ. no. 2, p. 13, pl. 4, figs. 20-22. Recent Foram., Southwest Texas. 
1954. "Rotalia" beccarif (Linné) variant A. Phleger, Am. Assoc. Petroleum Geol. Bull., v. 38, no. 4, p. 6́45, pl. 3, figs. 4-6. Recent Foram., Mississippi Sound.

1954. "Rotalia" beccaril (Iinné) variant A. Pariker, Harvard Coll. Mus. Corep. Zoology Bull vol. III, no. 10, p. 531, pl. 10, figs. 1, 5. Recent Foram., Northeastern Gulf of Mexico.

1954. Streblus beccarii (Linné) var. sobrinus (Shupack). Bandy, U. S. Geol. Survey Prof. Paper 254-F, p. 138, pl. 30, fig. 7. Recent Foram., Northern culf of Mexico.

Streblus beccarif var. sobrimus is very abundant in the Sound in areas of mixing. It is vere common in the open gulf.

Streblus beccarii (Linné) vär. tepious fCushman)

Plate 2, Figures $10 \overline{\mathrm{A}, \mathrm{B}, \mathrm{C}}$

1926. Rotalia beccaril (Linné) var. tepida Cushman, Carnegie Inst. Washington Pab., No. 344, (Dept. Marine Biology Papers, vol. 23), p. 79, pl. 1. Recent Foram., Porto Rico.

1953. "Rotalia" beccarif (Linne) variant B. Parker, et al., Cushman Found. Foram. Research, Spec. Publ. no. 2, p. 13, pl. 4, figs. 25-28. Recent Foram., Southwost Texas.

3.954. "Rotalia" beccaril (Linné) variants. Parker, Harvard Coll. Mus. Comp. Zoology Buli., vol. III, no. 10, p. 531, pl. 10, figs. 2, 6? Recent Foram., Northeastern Gulf of Mexico.

1954. "Rotalia" beccarii (Iinné) variants. Phleger, Am. Assoc. Petroleum Geol. Bull., vol. 38, no. 4, p. 645, pl. 3, figs. 7, 8, 9? Recent Foram., Kississippi Sound.

1956. non Streblus tepidus (Cushman). Bandy, U. S. Geol. Survey Prof. Paper 274-G, p. 197, pl. 31, fig. 2. Foram. Bcology, Northeastern Gulf of Mexico.

Streblus beccarii var. tepidus is cormon in areas of environmental mixing and abundant in the open gulf.

Trochamina macrescens $\mathrm{H}$. Bro Brady Plate 2, Figures 11A, B,C

1870. Trochamina inflata (Montagu) var. macrescens H. B. Brady, f fide Ann. Mag. Nat. Hist., ser. 4, vol. 6, p. 51, pl. 1, figs. 5a-c.7 
1953. Trochammina macrescens H. B. Bracy. Parker, et al., Cushman Found. Foram. Research, Spec. Publ. no. 2, p. 15, pl. 3, figs. 7, 8. Recent Foram., Southwest Texas.

1954. Trochammina macrescens H. B. Brady. Phleger, Am. Assoc. Petroleum Geol. Bull., vol. 38, no. 4, p. 646, pl. 3, fig. 24. Recent Foram., Mississippi Sound.

Trochamina macrescens is essentially a marsh species in all reports related to this study.

Trochamina cf. T. cchracea (williamson)

Plate 2, Figures $12 \mathrm{~A}, \mathrm{~B}, \mathrm{C}$

1858. Rotalina ochracea Williamson, W. C., [ fioje Royal Soc. London, p. 55, pl. 4, fig. 112, pl. 5, fig. 113.7 Recent Foram, Gr. Britain.

1884. Trochammina ochracea (Williamson) BaIkwill and Millet, $C$ fide Journ. Micro., vol. 3, p. 24, Fl. 1, fig. 7.7

1944. Trochammina ochracea (Williamson). Cushman, Cushman Lab. Foram. Research, Spec. Publ. no. 12, p. 19, pl. 2, figs. 12, 13. Recent Foram., New England.

Trochammina cf. T. ochracea is rather common as small percentages in Mississippi Sound. It becomes more abundant near the beach on Horn Island. 


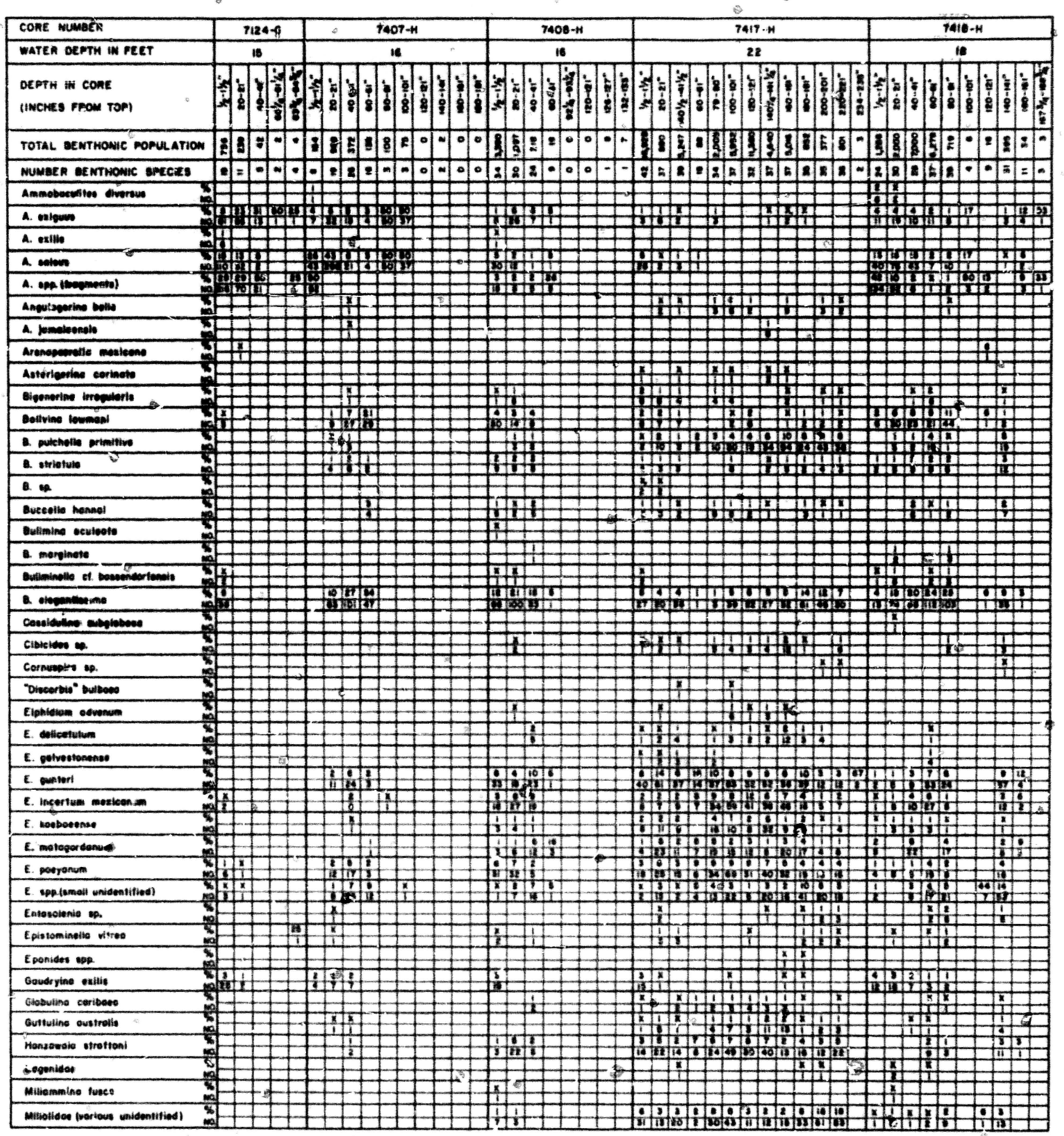

BENTHONIC FORAMINIFERAL OISTRIBUTIONS IN MISSISSIPPI SOUND CORES

$\%$ - ECCUARENCE IN PERCENT OF TOTAL BENTMONIC POPUI. ATIONS

NQ. OCCURAE NCE in ACTUAL NUmBER OF SPECIMENS COUNTED

$x$ - LEss than 0.5\% 



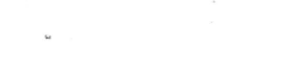

.

57

.

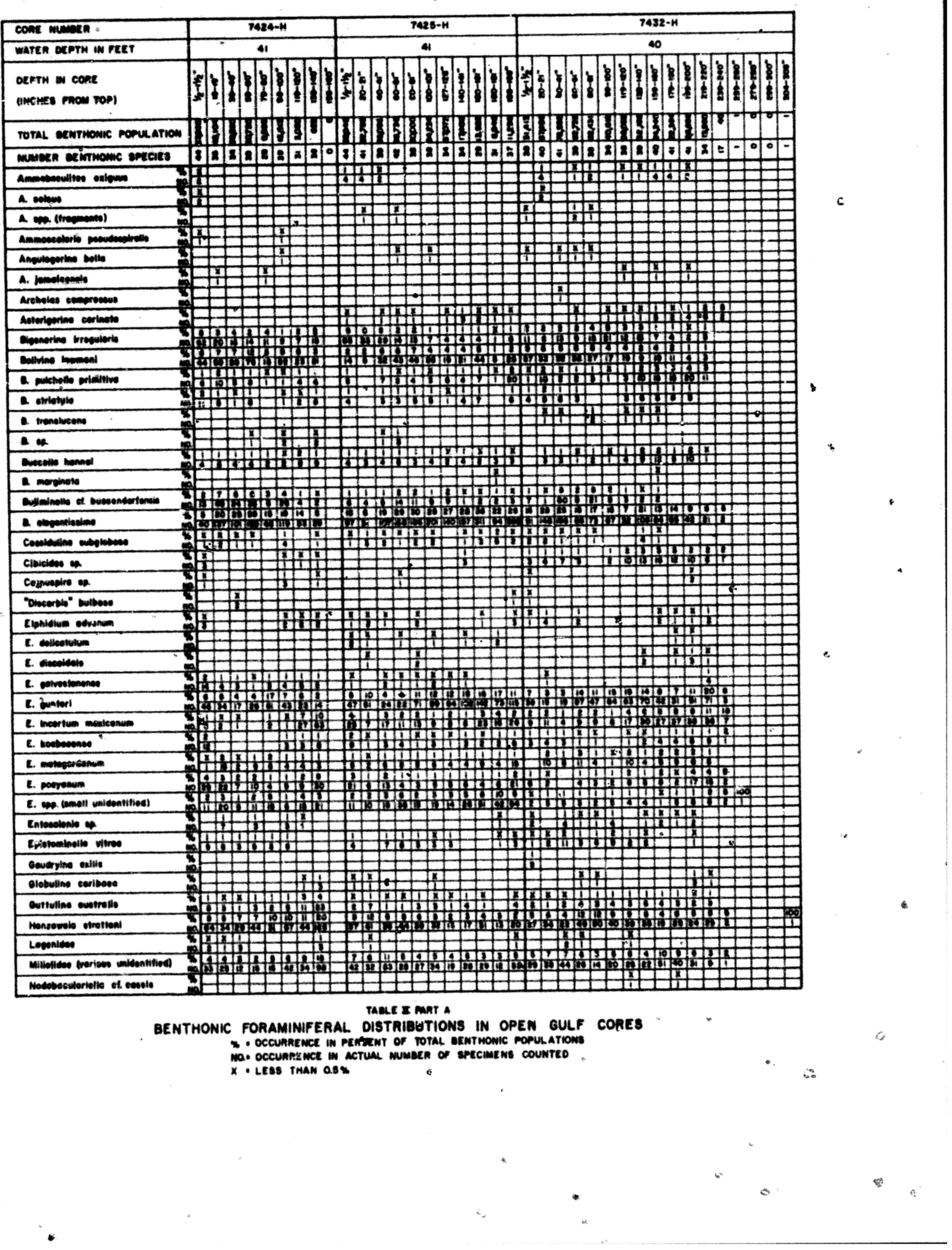




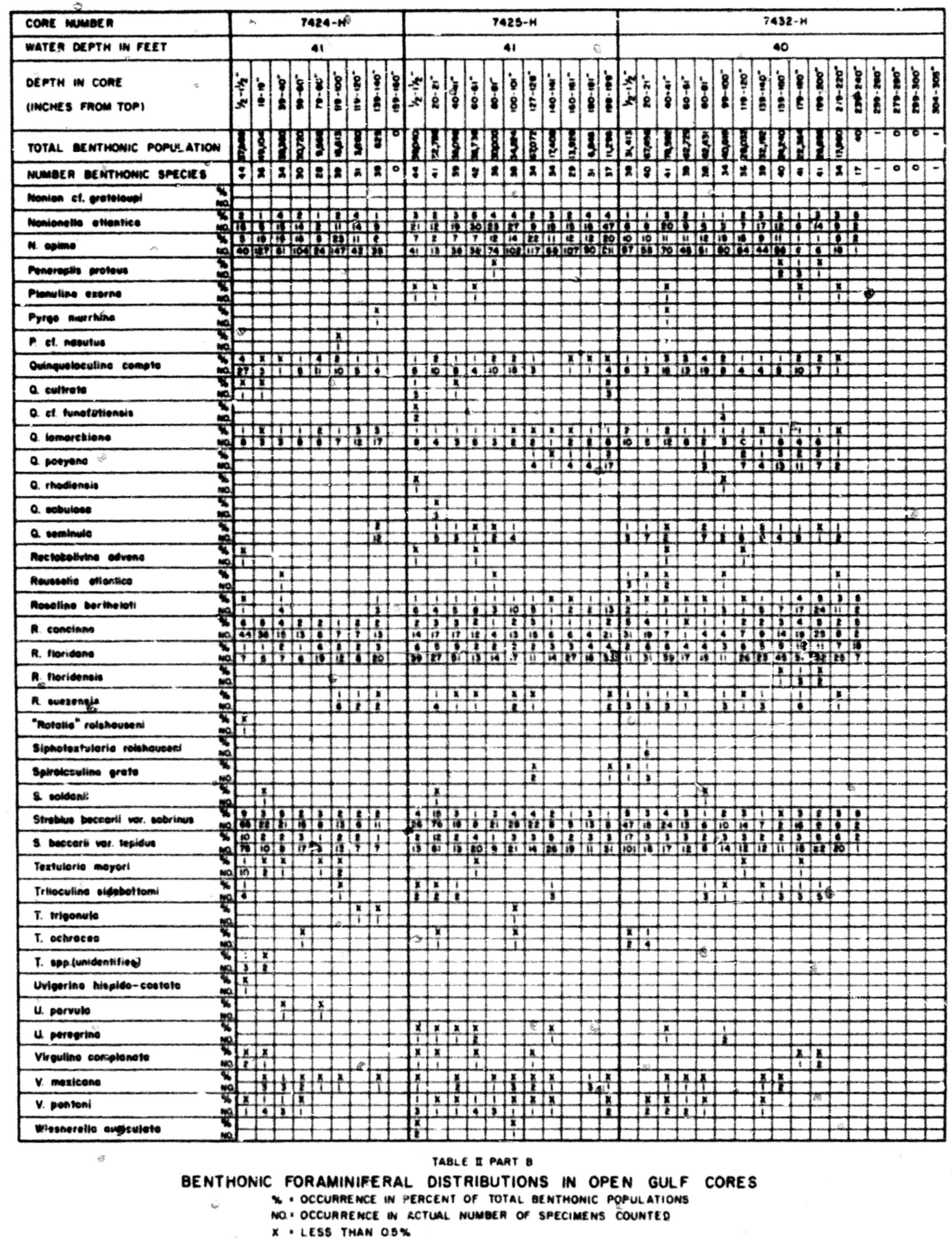




\begin{tabular}{|c|c|c|c|c|c|c|c|}
\hline cone mumaen & & $\frac{\pi}{2}$ & 8 & $\frac{2}{4}$ & & & $\frac{1}{2}$ \\
\hline WATEA DEPTH w FEET & 17 & 30 & ie & 14 & & & \\
\hline $\begin{array}{l}\text { OEPTH IN OSRE } \\
\text { (INOHES Fnow TOP) }\end{array}$ & & & & & & & \\
\hline TOTAL EENTHONIO MOPULATION & 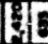 & & & 8 & & & \\
\hline MyMeen oentmomic smeies & E] & : & 2 & $2 \cdot 0$ & : 8 & & 8 \\
\hline 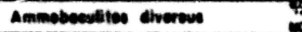 & & & & & & & \\
\hline A. anvono & & & & & & & \\
\hline A. selaven & & & & & & & \\
\hline A. ope (troeponombs) & & & & & & & \\
\hline Ammosectiorio omp & & & & & & & \\
\hline Anoviloperited bollo & & & & & & & \\
\hline Aremoparrobete merisene & & & & & & & \\
\hline Astorioering cosinate & & & & & & & \\
\hline Biponering in ingulerite & & & & & & & \\
\hline Colivine losement & & & & & & & \\
\hline a puichsolio primitivo & & & & & & & \\
\hline C. Atriotule & & & & & & & \\
\hline a. op & & & & & & & \\
\hline Oucsoltie nomaet & & & & & & & \\
\hline Busimine cevioefte & & & & & & & \\
\hline - moresinote & & & & & & & \\
\hline 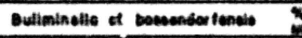 & & & & & & & 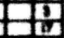 \\
\hline - olopentibuims & & & & & & & \\
\hline Oesoidutine warvele & & & & & & & \\
\hline C. onboloboses & & & & & & & \\
\hline Cibicides an & & & & & & & \\
\hline Cormuspive of & & & & & E & & \\
\hline Elphidium odvoever & & in & & & & & \\
\hline E. Solicotulum & & & & & E & & \\
\hline E. discoidate & & & & & $\frac{y}{1}$ & & II \\
\hline E polvesononomense & & $8 x$ & & & is & & i \\
\hline E. puntoet & & कीज & & T & कीज & & कीजी \\
\hline E. incertum mesiconum & & is & & & $\frac{1}{91}$ & & की: \\
\hline E. Hoobocennos & & $\frac{9}{12}$ & & & $\frac{1}{1}$ & & \\
\hline C. molopordenum & & $\frac{19}{91}$ & & & Hitis & 119 & fin \\
\hline E. poovenum & & it & & $t$ & Iit? & 格 & Iifi \\
\hline C. App ionell unidoentitiod) & & ati & & तit & in & & \\
\hline Epiotominotilo vilises & & $\begin{array}{lll}x \\
y\end{array}$ & & & 19 & & inth \\
\hline Goveryine oxtitio & & $\frac{\pi 4}{12}$ & & 7 & $\frac{7}{1}$ & & II: \\
\hline Glabuline coriboes & & \pm & & & $\theta$ & $\frac{\pi}{2}$ & $E$ \\
\hline Guttutine austrolis & & int & & & $\theta$ & & \\
\hline Mensamaie oftreltiont & & 高造 & & & ito & & 10: \\
\hline Moliemmine fusce & & \pm & 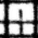 & & $E$ & & 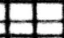 \\
\hline 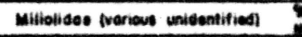 & & ติน & & & 6i & it & \\
\hline Modobocutariolle et conen & & & & & & & \\
\hline
\end{tabular}

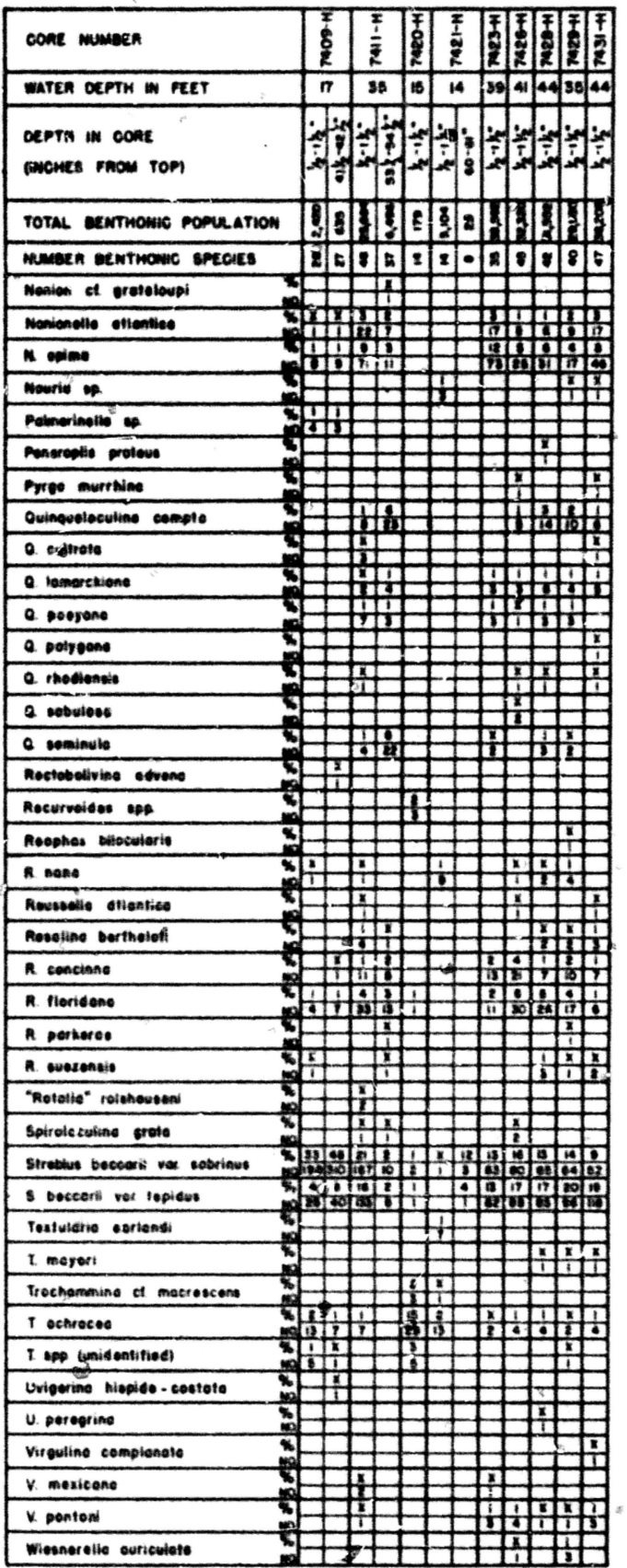

Wiesnor ollie suriculete

TABLE III

BENTHONIC FORAMINIFERAL DISTRIBUTIONS

* - OOOURRE MEE IN PUICENT OF TOTAL BENTHONIC POPULATIONS

NO- OCCURRENCE IN ACTUAL MUMEER OF SPECIVENS COUNTED

$x$ - LEss THAN $0.8 \%$ 
PLATE 1

(All magnifications are $70 \mathrm{X}$ unless otherwise stated)

Fj.g. 1. Ammobaculites exiquus Cushman and Bronnimann. Core $712 \mathrm{~L}-\mathrm{H}$, $\frac{T}{2}-I \frac{1}{2}$ inches. $\overline{A,}$ side view; $B$, front view.

Fig. 2. Ammobaculites salsus Cushman and Bromimann. Core $712 \mathrm{~L}-\mathrm{H}$, $\frac{1}{2}-1 \frac{1}{2}$ inches. $A$, sice view; $B$, front view.

Fig. 3. Bigenerina irregularis Phleger and Parker. Core 7417-H, $\frac{T}{2}-1 \frac{1}{2}$ inches. A, side view; $B$, front view.

Fig. 4. Bolivina lowmani Phleger and Parker. Core 7417-H, $\frac{1}{2}-1 \frac{1}{2}$ inches. A, side view; 3 , front view. $100 \mathrm{X}$

Fig. 5. Bolivina pulchella primitiva Cushman. Core $7417-\mathrm{H}, \frac{1}{2}-1 \frac{1}{\tilde{c}}$ inches. A, side view; $B$, front view.

Fig. 6. Bolivina striatula Cushman. Core 7417-H, $\frac{1}{2}-1 \frac{1}{2}$ inches. A, side view; B, front view.

Fig. 7. Buccella hannai (Phleger and Parker). Core $7417-\mathrm{H}, \frac{1}{2}-1 \frac{1}{2}$ inches. A, dorsal view; $B$, ventral view; $C$, apertural view.

Fig. 8. Buliminella bassendorfensis Cushman and Parker. Core 7417-H, $\frac{T}{2}-1 \frac{1}{2}$ inches. A, side view; B, front view.

Fig. 9. Buliminella elegantissima (d'Orbigny). Core 74l7-H, $\frac{1}{2}-1 \frac{1}{2}$ inches. $A$, side view; $B$, front view.

Fig. 10. Elphidium gunteri Cole. Core 7417-H, $\frac{1}{2}-1 \frac{1}{2}$ inches. A, side view; $B$, apertural viek.

Fig. 11. Elphidium incertum mexicanum Kornfeld. Core 7417-H, $\frac{1}{2}-1 \frac{1}{2}$ inches. A, side view; B, apertural view.

Fig. 12. Elphirium sp. cf. E. koeboeense Leroy. Core 74l7-H, $\frac{1}{2}-7 \frac{1}{2}$ inches. A, side view; $B$, apertural view.

Fig. 13. Elphidium matagordanum (Kornfeld). Core 7417-H, $\frac{1}{2}-1 \frac{1}{2}$ inches. $A$, side view; $B$, apertural view.

Fig. H. Elphidium poeyanum (d'Orbigny). Core $7417-\mathrm{H}, \frac{1}{2}-1 \frac{1}{2}$ inches. A, side view; $B$, apertural view (apertural face broken).

Fig. 15. Eistominella vitrea Parker. Core $7417-\mathrm{H}, \frac{1}{2}-1 \frac{1}{2}$ inches. $A$, dorsal view; $B$, ventral view; $C$, apertural view. I00X 
3.

Fig. 16. Gaudryina exilis Cushman and Bronnimann. Core $7 \mathrm{I} 24-\mathrm{H}, \frac{1}{2}-1 \frac{1}{2}$ inches. A, side view; $B$, front view. 100X

Fig. 17. Guttulina australis d'Orbigny. Core $7417-\mathrm{K}, \frac{1}{2}-1 \frac{1}{2}$ inches.

Fig. 18. Hanzawaia strattoni (Applin). Core $7417-\mathrm{H}, \frac{1}{2}-1 \frac{1}{2}$ inches. $A$, dorsal view; $B$, ventral view; $C$, apertural view.

Fig. 19. Nonionella atlantica Cushman. Core 7417-H, $\frac{1}{2}-1 \frac{1}{2}$ inches. $A$, dorsal view; $B$, ventral view; $C$, apertural view.

Fig. 20. Nonionella opima Cushman. Core $7417-\mathrm{H}, \frac{1}{2}-1 \frac{1}{2}$ inches. $A$, dorsal view; $B$, ventral view; $C$, apertural view.

Fig. 21. Nouria sp. Core 7124-H, $\frac{1}{2}-1 \frac{1}{2}$ inches. A, side view; B, apertural view.

Fig. 22. Planulina exorna Phleger and Parker. Core 7417-H, $\frac{1}{2}-1 \frac{1}{2}$ inches. A, dorsal view; $B$, ventral view; $C$, apertural view. 
PIALE 2

(Al] magnifications are $70 \mathrm{X}$ unless otherwise stated)

Fig. 1. Quinqueloculina compta Cushman. Core 74l7-H, $\frac{1}{2}-1 \frac{1}{2}$ inches. $\bar{A}$, side view; $\bar{B}$, front view; $C$, apertural view.

Fig. 2. Quinqueloculina lamarckiana d'Orbigny. Core 74l7-H, $\frac{1}{2}-1 \frac{1}{2}$ inches. A, side view; B, front view; C, apertural view.

Fig. 3. Quinqueloculina poeyana d'Orbigny. Core $7417-\mathrm{H}, \frac{1}{2}-1 \frac{1}{2}$ inches. A, side view; $B$, front view; $C$, apertural view.

Fig. 4. Quinqueloculina semtnula (Iinne). Core $7417-\mathrm{H}, \frac{1}{2}-1 \frac{1}{2}$ inches. A, sigde view; $B$, front view; $C$, apertural view.

Fig. 5. Rosalina bertheloti d'Orbigny. Core 7417-H, $\frac{1}{2}-1 \frac{1}{2}$ inches. $A$, dorsal view; $B$, ventral view; $C$, apertural view.

Fig. 6. Rosalina concinna (H. B. Brady) C Core 7417-H, $\frac{1}{2}-1 \frac{1}{2}$ inches. $\vec{A}$, dorsal view; $\vec{B}$, ventral view; $C$, apertural view.

Fig. 7. Rosalina floridana (Cushman). Core 74l7-H, $\frac{1}{2}-1 \frac{1}{2}$ inches.

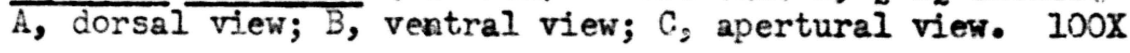

Fig. 8. Rosalina suezensis (Said). Core 7417-H, $\frac{1}{2}-1 \frac{1}{2}$ inches. A, dorsal view; $B$, ventral view; $C$, apertural view.

Fig. 9. Streblus beccarii (Iinne) var. sobrinus (Shupack). Core 7417-H,

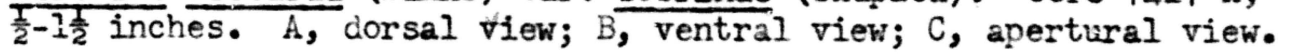

Fig. 10. Streblus beccarii (Iinnej var. tepidus (Cushman). Core 7417-H, $\frac{1}{2}-1 \frac{1}{2}$ inches. A, dorsal view; $B$, ventral view; $C$, apertural view.

Fig. 11. Trochammina macrescens H. B. Brady. Core $712 L_{i}-\mathrm{H}, \frac{1}{2}-1 \frac{1}{2}$ inches. A, dorsal view; B, ventral view; C, apertural view. I00X

Fig. 12. Trochammina sp. cf. T. ochracea (Williamson). Core 7124-H, $\frac{1}{2}-1 \frac{1}{2}$ inches. A, dorsal view; $B$, ventral view; 0 , apertural view. $100 \mathrm{X}$ 


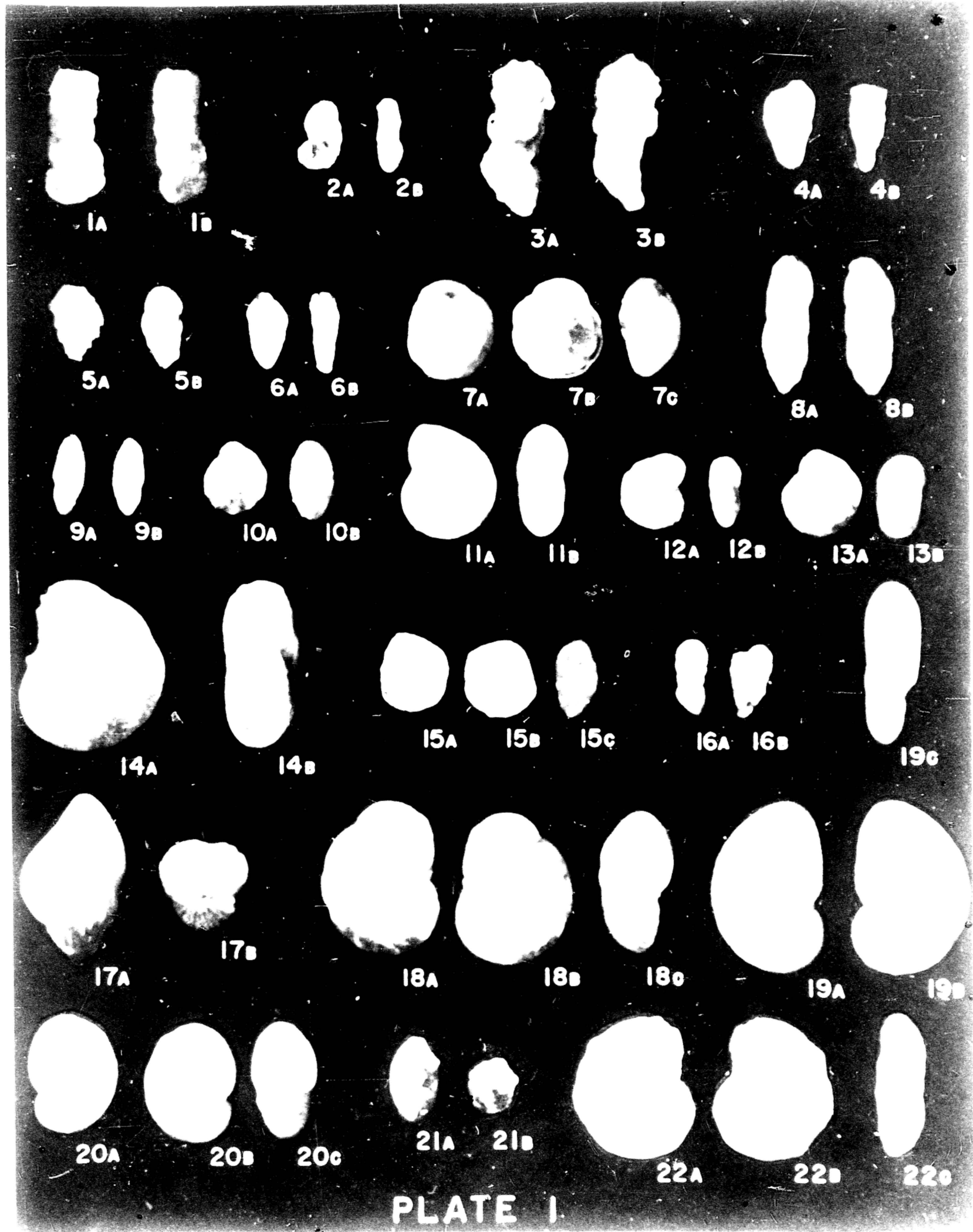




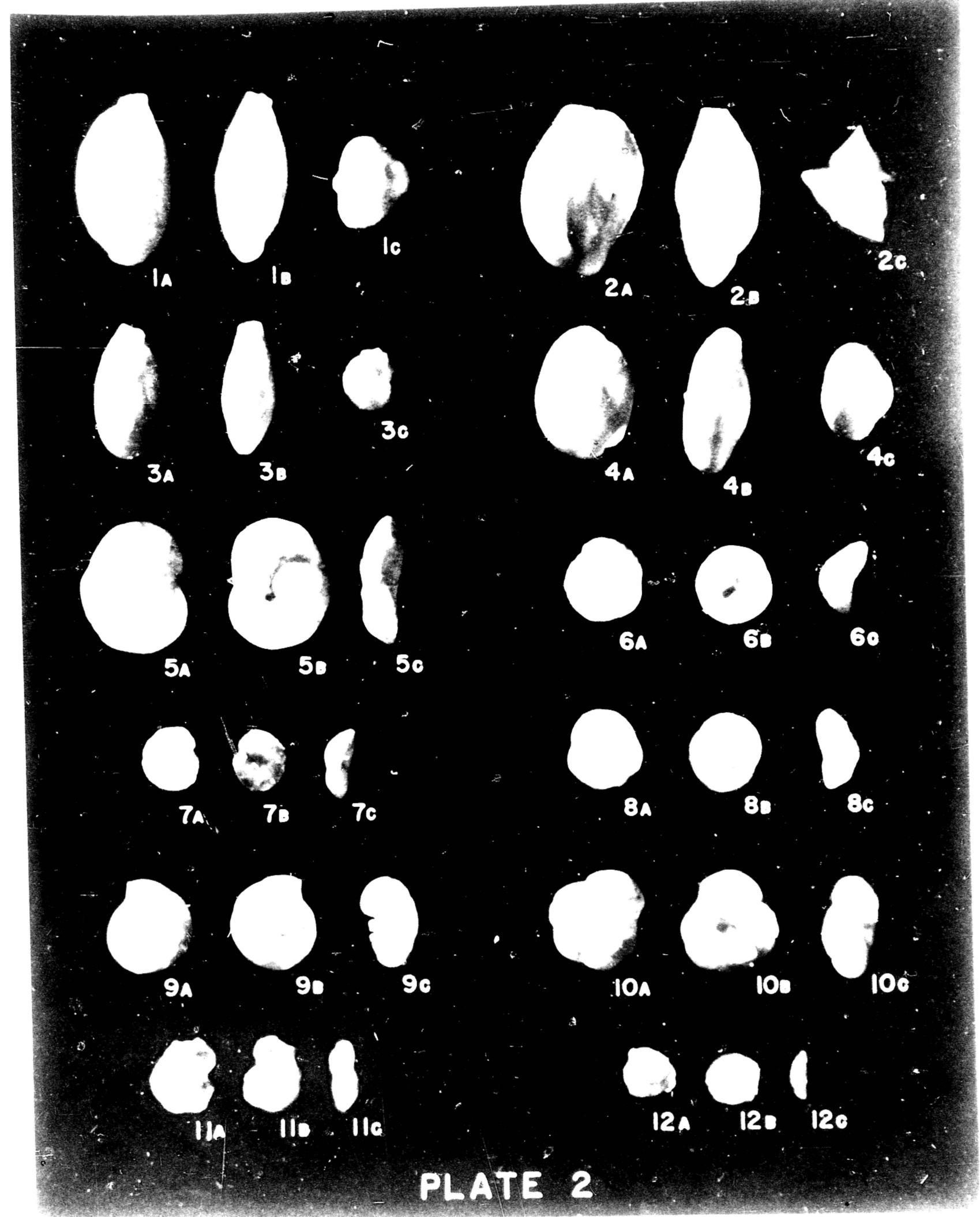


University Libraries

University of Missouri

Digitization Information for Theses and Dissertations project. Scanned from microfilm; no subsequent editing done.

Local identifier

Source information

Identifier

Format

Content type

Notes

Capture information

Date captured

Scanner manufacturer/model ScanPro 3000 /e-ImageData

Scanning software

Optical resolution

Compression

Color settings

File types

Notes

Derivatives - Access copy
Microfilm reel\# T1958-59-T1958-70

Microfilm

Text

2019

PowerScan $3000(\mathrm{TM})$ V5.341

$600 \mathrm{dpi}$

LZW

bitonal

tiff

Scanned from microfilm; no editing done.
Editing software

Resolution

Color

File types

Notes
Photoshop

600 dpi

grayscale

pdf

Converted from tiff to pdf using Adobe Acrobat Pro DC. 